OECDpublishing

\title{
MIGRATION IN ASIA:
}

WHAT SKILLS FOR THE FUTURE?

OECD DEVELOPMENT POLICY PAPERS

July 2021 No. 40 



\title{
OECD Development Policy Papers
}

July 2021 - No. 40

\section{Migration in Asia: What skills for the future?}

\author{
By Catherine Gagnon and Jason Gagnon
}


This work is published under the responsibility of the Secretary-General of the OECD. The opinions expressed and arguments employed herein do not necessarily reflect those of the OECD, its Development Centre or of their member countries.

This document, and any map included herein, are without prejudice to the status of or sovereignty over any territory, to the delimitation of international frontiers and boundaries and to the name of any territory, city or area.

This document was authorised for publication by Mario Pezzini, Director of the Development Centre and Special Advisor to the OECD Secretary-General on Development.

Keywords: international migration; regional co-operation; future of work; skills; employment; labour migration

JEL classification: F22; O15; J24; J61; F66

(C) OECD 2021 


\section{Abstract}

The world is increasingly facing a technologically changing employment landscape and such changes are directly affecting the future demand for skills. For regional economies built on labour migration, the impending changes will affect migrants and their families, their countries of origin and the recruitment systems they are attached to - and ultimately disrupt the development benefits of migration. This paper investigates how the future of the employment landscape will affect migration within the Abu Dhabi Dialogue, a regional consultative process for migration in Asia. It investigates the impending changes in the demand for skills in countries of destination, how such changes will affect migration processes and whether countries of origin are ready for the changes. It provides recommendations on how regional consultative processes can foster dialogue between key actors from both countries of origin and destination to better navigate future changes and ensure a smooth transition. 


\section{Foreword}

The current on-going industrial revolution, driven by a range of technologies blurring the lines between the physical, digital and biological spheres, is dramatically transforming the world economy, affecting virtually every sector from trade to gender roles, or production processes to environmental health. These changes are profoundly affecting the labour market with important implications for the future of work and demand for skills. This in turn has significant ramifications for another global megatrend: the growth of international labour mobility. The most in demand skills are slated to be increasingly technology related, specifically in the fields of Science, Technology, Engineering and Math (STEM), combined with a set of soft skills that complement automated and technologically-driven jobs - skills that are hard to define or that prospective students in many low- and middle-income countries deem to be less desirable. These impending changes will affect migrants and their families, their countries of origin and the recruitment systems they are attached to - and ultimately disrupt the development benefits of migration. This paper presents the policy context of the fallout and opportunities of such changes. It places the debate in Asia, a region from which millions of labour migrants continue to work in Gulf countries, sending or returning home with substantial savings, which are then invested in their countries of origin. The paper is set in the broader discussion on the importance of ensuring more inclusive multilateral dialogue, and the policy opportunity to create situations that benefit both countries of origin and destination. 


\section{Acknowledgements}

This paper was prepared by Catherine Gagnon, intern at the OECD Development Centre and Jason Gagnon, Lead Economist on Migration and Skills at the OECD Development Centre, under the overall guidance of Federico Bonaglia, Deputy Director of the OECD Development Centre. An earlier version of the paper was prepared for and presented at the Abu Dhabi Dialogue (ADD) Senior Officials' Meeting in May 2021. The authors are thankful for comments received during the meeting, and for guidance and feedback from the ADD Secretariat, namely Alia Ibrahim Mohamed Abdulrahim, Alex Zalami and Rasha Assem Saleh. The authors are also grateful to Elizabeth Nash and Anne Thomas regarding publication assistance. 


\section{6}

\section{Table of contents}

Abstract 3

Foreword $\quad 4$

Acknowledgements $\quad 5$

$\begin{array}{ll}\text { Abbreviations and acronyms } & 7\end{array}$

1 What is the current employment context in the Gulf Cooperation Council countries? 9

What future changes are expected in the Gulf Cooperation Council labour market? 11

Digitalisation and automation are transforming the employment landscape 13

Other underlying changes in human capital and the labour force 14

2 What is the current state of labour migration in the Abu Dhabi Dialogue area? 15

Where do migrants come from? 16

What changes in the migrant labour force? $\quad 17$

3 What are the skills of the future in the Abu Dhabi Dialogue area? 19

There is more emphasis on specific tasks, but soft skills are ill-defined 20

How ready are countries of origin for the change in employment landscape in the Abu Dhabi

Dialogue area?

Reimagining labour markets and education systems for $21^{\text {st }}$ century tasks and soft skills 22

Adapting strategies for the future of (migrant) labour demand 23

4 How can countries adapt to changing labour migration needs? 26

What is the role of regional consultative processes on migration in preparing for the future demand in skills?

Annex A. Strategic Development Plans in Gulf Cooperation Council countries 30

Annex B. Pre-departure orientation and skilling strategies for migrant workers, by Abu Dhabi Dialogue country of origin 


\section{FIGURES}

Figure 1. Sectoral shares of GDP in GCC countries (\%, 2000, 2010, 2019)

Figure 2. Employment distribution by economic activity in GCC countries (\%, 2000, 2010, 2019) 11

Figure 3. Human capital, competitiveness and sustainability are high amongst GCC priorities 12

Figure 4. Employment distribution by economic activity in ADD countries of origin (\%, 2000, 2010, 2019) 21

Figure 5. Gross school enrolment at tertiary level in ADD countries of origin (\%)

Figure 6. Individuals using the Internet in ADD countries of origin (\% of population)

Figure 7. Development strategies need to be continuously updated in the light of skills-related changes to benefit both sending and receiving countries

\section{TABLES}

Table 1. Number of migrants and population size in the GCC countries (2020)

\section{Follow OECD Publications on:}

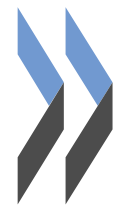

Y http://twitter.com/OECD_Pubs

$f h t t p: / / w w w . f a c e b o o k . c o m / O E C D P u b l i c a t i o n s$

in. http://www.linkedin.com/groups/OECD-Publications-4645871

- http://www.youtube.com/oecdilibrary 


\section{Abbreviations and acronyms}

ADD

Al

CoD

$\mathrm{CoO}$

COVID-19

GCC

GDP

ICT

ILO

IT

KSA

L\&D

MoU

NRI

PDO

RMCS

TMC

TVET

UAE

WEF

WHO
Abu Dhabi Dialogue

Artificial Intelligence

Country of Destination

Country of Origin

Coronavirus disease 2019

Gulf Cooperation Council

Gross Domestic Product

Information and Communication Technology

International Labour Organization

Information Technology

Kingdom of Saudi Arabia

Learning \& Development

Memorandum of Understanding

Network Readiness Index

Pre-departure Orientation

Regional Model Competency Standards

Technology, Media and Communications

Technical and Vocational Education and Training

United Arab Emirates

World Economic Forum

World Health Organisation 


\section{What is the current employment context in the Gulf Cooperation Council countries?}

The world is increasingly facing a technologically changing employment landscape. This is particularly true for Abu Dhabi Dialogue (ADD) member states ${ }^{1}$, where migrant countries of destination (CoDs) in particular, namely the Gulf Cooperation Council (GCC) states of Bahrain, Kuwait, Oman, Qatar, the Kingdom of Saudi Arabia (KSA) and the United Arab Emirates (UAE), as well as Malaysia, are diversifying their economies and moving toward capital- and technology-intensive industries.

Considering the sizeable migration flows between ADD member countries, such a shift has direct consequences on employment prospects and implications for both countries of origin (CoOs) and CoDs. Migrants contribute to a high degree to the development of CoDs through their labour. Migrant workers are also important development agents for $\mathrm{CoO}$ s as they remit money back home and return with new social, financial and human capital. Remittances as a percentage of GDP in major ADD CoOs, for example range from $3 \%$ to $24 \%$ (World Bank, 2021a). Changes may therefore translate to important disruptions in the benefits and links between migration and development in the region.

The future of migration flows and their contributions to ADD economies will depend on the adaptability of member states to the transforming employment outlook and demand in skills. But what kind of transformation will they face and which skills will be in demand? This paper explores the ways the future of work will affect the types and demand of skills in the ADD corridors. It portrays the current and future employment contexts in both $\mathrm{CoOs}$ and $\mathrm{CoDs}$, places the analysis within the context of migration in the region and identifies the skills needed in relation to it. It provides five areas where regional consultative processes can play a role in fostering a better preparation for the ancipated changes and a smooth transition for both CoDs and CoOs: by mapping skills, recognising credentials, promoting partnerships on skills, data as well as between employers and educational institutions.

The GCC economies are structurally similar and rely heavily on the growth of the hydrocarbon sector. While the oil and gas sector has been and remains the biggest contributor to GDP in the region, its share has fallen significantly over the past 20 years. Mining and quarrying accounted for $37 \%$ in 2000 and $41 \%$ in 2010 on average across GCC countries. Only Bahrain and the UAE were less dependent on natural resources with less than $30 \%$ of their GDP linked to mining and quarrying. In 2019, this share had fallen to $29 \%$ for GCC countries on average, while all other contributing sectors of the economy had grown. The current largest sectors outside of energy are finance and real estate; manufacturing (chemicals and metal industries); public administration and defence; wholesale, retail trade and hospitality; and construction (Figure 1).

\footnotetext{
1 The ADD is a regional consultative process on migration in Asia. The 17 ADD member states consist of the following: Afghanistan, Bahrain, Bangladesh, India, Indonesia, Kuwait, Malaysia, Nepal, Oman, Pakistan, the Philippines, Qatar, Saudi Arabia, Sri Lanka, Thailand, the United Arab Emirates and Viet Nam.
} 
Figure 1. Sectoral shares of GDP in GCC countries (\%, 2000, 2010, 2019)

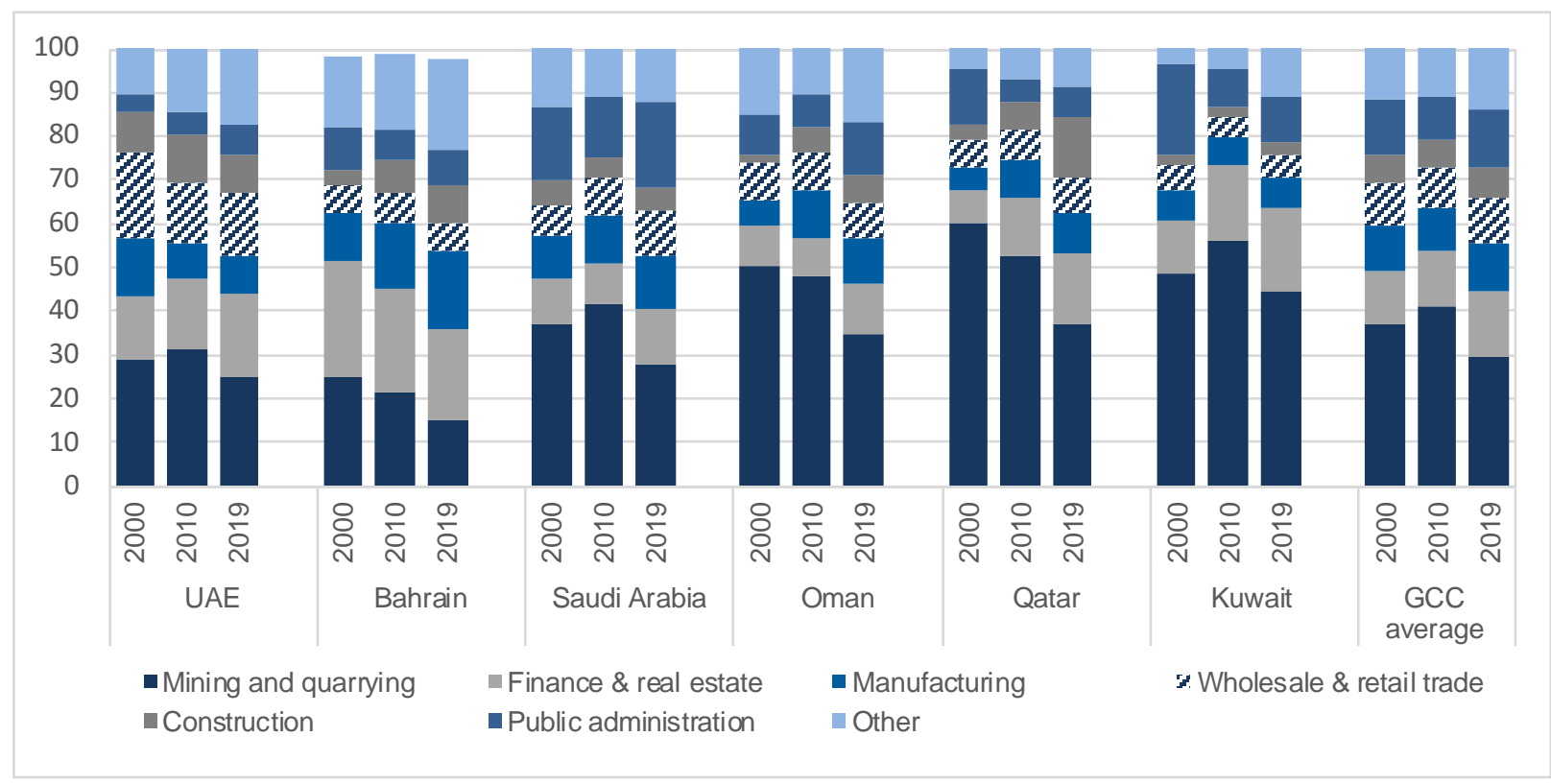

Note: "Other" comprises agriculture; electricity, transport; education, health, and private households with employed persons.

Source: GCC Stat (2019), www.gccstat.org, accessed in February 2021.

The oil industry does not drive employment in the GCC countries, however. In fact, the share of employment in GCC economies does not follow the aforementioned corresponding sectoral contributions to GDP. The biggest sector of employment in GCC countries is the construction industry rather than oil and gas, followed closely by wholesale and retail trade, and public administration. In Bahrain, the UAE and Saudi Arabia, the manufacturing sector also plays an important role and employs a comparatively larger share of people than in Oman, Qatar and Kuwait. The UAE's real estate and business sector stands out as it employs twice as many people as in other GCC countries (Figure 2; ILO Stat, 2020a). 
Figure 2. Employment distribution by economic activity in GCC countries $(\%, 2000,2010,2019)$

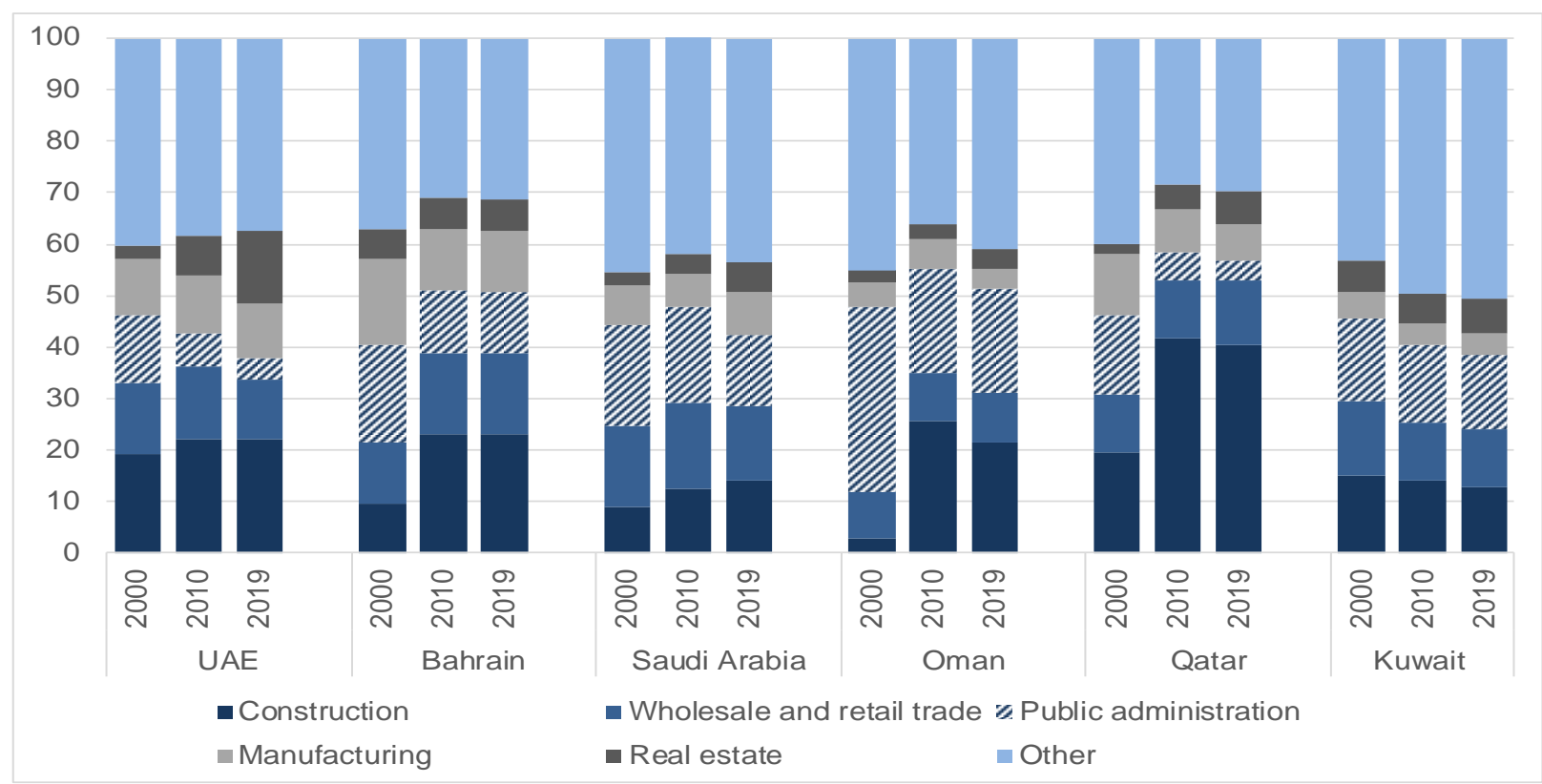

Note: "Other" includes transport; accommodation and food services; financial and insurance activities; education; health; entertainment; private households with employed persons; agriculture; mining and quarrying; and utilities.

Source: ILO STAT (2020a), ILO modelled estimates,

www.ilo.org/shinyapps/bulkexplorer16/?lang=en\&segment=indicator\&id=EMP_2EMP_SEX_ECO_DT_A, accessed in February 2021.

\section{What future changes are expected in the Gulf Cooperation Council labour market?}

Change in the major sectors of employment within GCC countries is underway. Economic diversification into non-oil sectors has become a high priority since 2014, following the collapse of oil prices (Fattouh and Sen, 2021), and the current COVID-19 pandemic provides the impetus to further push this transition. In fact, strategic development plans have been adopted across all six GCC countries in recent years, ensuring that the transition away from oil dependence is navigated from the top, with adequate resources, and with the objective of modernising and further developing the private sector, specifically fostering future growth sectors Figure 3; Annex A). Generally, the strategies aim at diversifying the economies into advanced, value-adding industries and creating knowledge-based economies. This implies a transition away from low-cost and labour-intensive industries to capital-intensive industries requiring high-skilled labour (Shayah and Sun, 2019). 
Figure 3. Human capital, competitiveness and sustainability are high amongst GCC priorities

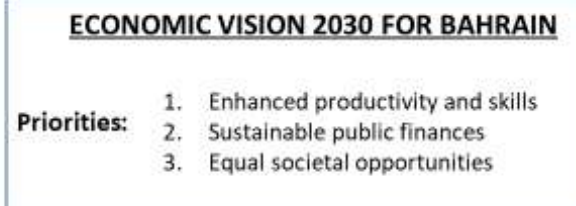

\section{ECONOMIC VISION 2030 FOR BAHRAIN}

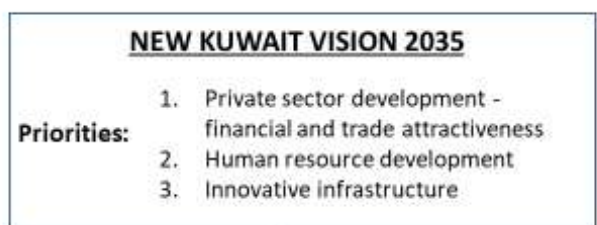

QATAR NATIONAL VISION 2030

1. Culture

2. Sustainable development

3. National and expatriate

labour force development

4. Education

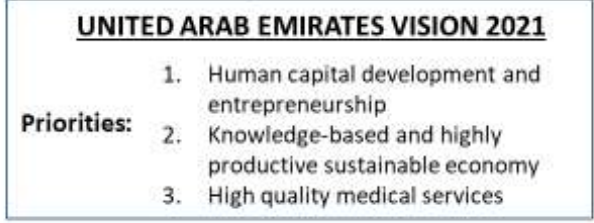

Source: Authors, based on the strategic development plans of Bahrain, Kuwait, KSA, Oman, Qatar and UAE.

In addition to shifting towards higher value sectors, national plans prioritise economic diversification, with infrastructure, renewable energy, manufacturing, tourism, retail and finance targeted as strategic sectors. Oman, for example, aims to increase the non-oil share of its GDP from $61 \%$ in 2017 to $92 \%$ in 2040 (Vision 2040, Government of Oman, 2018). The most common objectives for diversification are in the following domains:

- Investment in infrastructure is highlighted in GCC countries' development visions as vital to keep the pace with the changing economic landscape, especially infrastructure facilitating new digital and data technologies (e.g. high-speed broadband, mobile networks, communications satellites). Increased connectedness between GCC countries could spur a new ecosystem in the region.

- The renewable energy sector is expected to grow and create more jobs in GCC countries, an effort led by the UAE, which accounts for $70 \%$ of the GCC renewable energy capacity, followed by Saudi Arabia (17\%) and Kuwait (10\%) (World Bank, 2019).

- The manufacturing sector, deeply disrupted by automation and digitalisation, is another sector of growth in GCC countries, where a 'fourth industrial revolution', a sweeping term referring to the ongoing automation of traditional manufacturing and industrial practices, is under way. ${ }^{2}$ New technologies and methods, such as decentralised manufacturing, the Internet of things (IoT), robotics, remote monitoring and localised distribution, offer reduced costs and efficiency gains.

- GCC countries are also turning to tourism to diversify their economy and seize the opportunities provided by their cultural heritage, through investment in major air traffic hubs, historic and natural sites and festivals (Hilal, 2020).

\footnotetext{
${ }^{2}$ Key components of the fourth industrial revolution include automation, artificial intelligence (Al), big data analytics, blockchain technology, the Internet of Things (IoT) and 3D printing (OECD, 2018b).
} 
- The financial sector across the region has embraced new technologies, namely Fintech innovative technologies and platforms that either compete with or augment traditional financial services. Led by the UAE, this shift involves digital banking, crowdfunding platforms, robo-advising and crypto-asset exchanges (World Bank, 2019). These expanding sectors will require more specialised labour as they develop, but with different skill sets than previously dominant industries.

\section{Digitalisation and automation are transforming the employment landscape}

Digitalisation underpins the economic transformation of the region in all sectors and GCC countries are positioning themselves relatively well in terms of readiness for the future. According to the 2020 Network Readiness Index (NRI), a model based on four pillars seeking to evaluate the ability of countries to exploit the opportunities offered by information and communications technology (ICT) - Technology, People, Governance, and Impact -, the UAE figures in the top quartile, ranking $30^{\text {th }}$ among 134 countries. The UAE ranks first in the world in terms of "ICT usage among its population" (people pillar) and third in terms of "government promotion of investment in emerging technologies". The UAE is followed in the ranking by

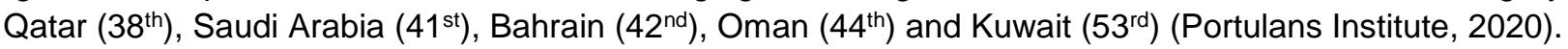

The shift towards automation, accelerated by the current COVID-19 pandemic, is another trend affecting the employment landscape, fuelled by the availability of new technologies and the desire to be less reliant on an external labour force. The potential of scaling up automation is high in GCC countries, especially in sectors where low- to semi-skilled and cheap migrant labour is employed to perform tasks that could be accomplished by machines.

Automation will mainly affect low- to semi-skilled jobs, as well as employees with less working experience, resulting in a skill bias in favour of high-skilled workers (OECD, 2020). Moreover, a report on automation in OECD countries finds that low-skilled workers most at risk of being affected by automation are less likely to participate in on-the-job training. It also found that they receive fewer hours of professional training than workers performing non-automatable tasks (OECD, 2018a). The tasks likely to be automated by new technologies are mostly routine manual tasks, such as assembly line work, and routine cognitive tasks, such as counting and dispensing cash in a bank (ADB, 2018). The share of work activities that could be automated given current technologies was estimated to be $45 \%$ for GCC countries in 2018, a level similar to that of the United States (46\%) and the "Big 5" European countries ${ }^{3}(47 \%)$. Manufacturing as well as transport and warehousing are the two sectors where jobs have the greatest automation potential in GCC countries (58\% on average). Other important sectors in GCC labour market, such as retail and wholesale trade, and construction also have on average more than $50 \%$ of automatable activities (Aus dem Moore et al., 2018).

The economic and health impacts of the COVID-19 pandemic could have mixed effects on the automation process in different sectors however. Considering the various lockdown measures and rapid transition to teleworking as well as the dire impacts on business and public finances, the push for technological innovation could precipitate the transition towards automation in various industrial sectors. According to the World Economic Forum's Future of Jobs Report 2020, 50\% of business leaders surveyed globally in 2020 stated that they had accelerated the automation of tasks in their companies as a result of the pandemic (WEF, 2020). On the other hand, the dismissal of workers in many countries and industries as well as the rising global unemployment rate may increase the supply of workers willing to accept lower wages and conditions, which could counter the progress of automation.

\footnotetext{
${ }^{3}$ France, Germany, Italy, Spain and the United Kingdom.
} 


\section{Other underlying changes in human capital and the labour force}

In addition to the digital and automated transformation happening in the employment landscape, two other key trends are changing the labour market context: the low rate of technical education enrolment and the growing participation of women.

Technical and Vocational Education and Training (TVET) enrolment in GCC countries is low, reflecting the general attitude toward this type of education despite GCC governments' investments as part of their economic vision plans (Khan et al., 2017). Enrolment in vocational programmes at the upper secondary level is less than 2\% in Oman, Saudi Arabia and Qatar, 2.5\% in the UAE and 4\% in Kuwait. Bahrain has higher enrolment, however, than other GCC states with $14 \%$ of upper secondary level students pursuing vocational education in 2018. TVET options remain mostly limited to men, which explain the low share of female students in these programmes (UNESCO-UNEVOC, 2018).

The labour force participation of women has also increased sharply since 2000 and represent an opportunity for GCC countries. With female labour participation rates varying from $45 \%$ to $57 \%$ in 2020 , Qatar, the UAE, Kuwait and Bahrain have significantly higher participation than Oman (36\%) and Saudi Arabia (22\%) (ILO Stat, 2019). Nonetheless, half of Saudi Arabian university graduates are women, an asset that is strongly considered in Saudi Arabia's development strategy, which aims to increase women's participation into the workforce to $30 \%$ by 2030 (Vision 2030, Government of Saudi Arabia, 2016). Measures to improve the employability of women could help leverage the region's human capital and fill labour gaps, specifically those adapted to new technologies (World Bank, 2019). 


\section{What is the current state of labour migration in the Abu Dhabi Dialogue area?}

The GCC economies have grown rapidly over the last decades. To sustain economic growth and fill labour gaps in key sectors of the economy, GCC countries strongly rely on migrant workers, a large share of them originating from Southeast and Southern Asia. The foreign-born population in GCC countries totalled nearly 31 million and represented $53 \%$ of the overall GCC population in 2020, with the highest shares found in the UAE (88\%), Qatar (77\%) and Kuwait (73\%) (Table 1).

Table 1. Number of migrants and population size in the GCC countries (2020)

\begin{tabular}{l|c|c|c}
\hline Country & Number of migrants & Total population & $\begin{array}{c}\text { Share of migrants in total } \\
\text { population }\end{array}$ \\
\hline Bahrain & 0.9 million & 1.7 million & $55 \%$ \\
\hline Kuwait & 3.1 million & 4.3 million & $73 \%$ \\
\hline Oman & 2.4 million & 5.1 million & $46 \%$ \\
\hline Qatar & 2.2 million & 2.9 million & $77 \%$ \\
\hline Kingdom of Saudi Arabia & 13.4 million & 34.8 million & $39 \%$ \\
\hline United Arab Emirates & 8.7 million & 9.9 million & $88 \%$ \\
\hline Total & 30.8 million & 58.7 million & $53 \%$ \\
\hline
\end{tabular}

Source: Authors' calculations, based on UNDESA (2019) and UNDESA (2020).

The sizeable share of migrants partly reflects skill shortages in the domestic workforce. GCC economies have a dual labour market in which local citizens typically work in the public sector and migrants typically work in the private sector. For citizens, public sector employment is more attractive in terms of salary and social benefits (World Bank, 2018a). Considering this dynamic, migrant workers in GCC countries complement the skill sets of nationals. The specific sectors in which migrants work vary across GCC countries, and depend on skills, gender and country of birth.

Migrants to GCC countries typically take positions as low- to semi-skilled workers mainly in the construction and domestic sectors. They also account for important shares of the labour force in agriculture, oil and gas, manufacturing, hospitality and transportation (ILO, 2021). In the UAE, for example, 50\% of the foreignborn population work in semi-skilled jobs as plant and machine operators, skilled agricultural and fishery labourers, trades workers, clerks and assemblers. Another $20 \%$ of foreign workers are employed in lower skilled jobs as cleaners and helpers as well as labourers in agriculture, construction, manufacturing, food 
preparation and transport. ${ }^{4}$ Such shares differ from the native population where $58 \%$ work in highly skilled occupations, as managers, officials, professionals and technicians and only $5 \%$ work in low-skilled employment (ILO Stat, 2020b).

\section{Where do migrants come from?}

Not all CoOs within the ADD area have strong migration ties to GCC member states. The primary countries of origin to GCC countries in the ADD area are Bangladesh, India, Indonesia, Nepal, Pakistan, the Philippines and Sri Lanka, where at least $25 \%$ of all emigrants originating from each of these countries lives in a GCC member country. For Pakistan (53.9\%) and India (53.5\%), more than half of the total emigrant population lives there (Table 2). The potential for disruption in labour migration is therefore high. One tangible example is the amount of remittances, which consists of at least $5 \%$ of GDP in six countries, and as high as $23.5 \%$ in Nepal. Any change in migration flows would have immediate effects on the home country's economy.

Table 2. Number of emigrants from ADD countries of origin in the GCC countries (2020)

\begin{tabular}{l|c|c|c|c}
\hline Country & Number of emigrants & $\begin{array}{c}\text { Total number of emigrants } \\
\text { in GCC countries }\end{array}$ & $\begin{array}{c}\text { Share of total } \\
\text { emigration }\end{array}$ & $\begin{array}{c}\text { Remittances as a } \\
\text { percentage of GDP }\end{array}$ \\
\hline Afghanistan & 5.9 million & 0.5 million & $8.5 \%$ & $4.1 \%$ \\
\hline Bangladesh & 7.4 million & 3.4 million & $46.6 \%$ & $6.6 \%$ \\
\hline India & 17.9 million & 9.6 million & $53.5 \%$ & $3.1 \%$ \\
\hline Indonesia & 4.6 million & 2.3 million & $49.7 \%$ & $0.9 \%$ \\
\hline Nepal & 2.6 million & 0.8 million & $31.3 \%$ & $23.5 \%$ \\
\hline Pakistan & 6.3 million & 3.4 million & $53.9 \%$ & $9.9 \%$ \\
\hline Philippines & 6.1 million & 1.7 million & $27.6 \%$ & $9.6 \%$ \\
\hline Sri Lanka & 2.0 million & 0.9 million & $45.2 \%$ & $8.8 \%$ \\
\hline Viet Nam & 3.4 million & 0.0 million & $0.0 \%$ & $5.0 \%$ \\
\hline
\end{tabular}

Source: Authors, based on UNDESA (2019), UNDESA (2020) and World Bank (2021a).

Specific laws and policies govern labour migration in the $\mathrm{CoOs}$, regulating the qualifications and conditions needed for overseas employment. Policies in all countries include some form of mandatory pre-departure orientation (PDO) to prepare workers for their employment abroad, aiming to raise awareness and basic knowledge of migrants on society and the economy in the CoDs and on their rights as workers. More specifically, trainings usually focus on the working conditions in the CoD, labour laws and contract, customs and culture of the $\mathrm{CoD}$, rights and responsibilities of migrants, health concerns, as well as some capacity development such as financial literacy. In certain countries or migration corridors, basic language training and sector-specific skills training are also offered (Annex B; Colombo Process, 2021).

CoOs have responded to the impending shift in the employment landscape by implementing strategies to upskill their population for employment abroad. Countries like Bangladesh, Pakistan and the Philippines, where emigrants have historically been typically of lower skill, now aim to send semi-skilled and skilled migrants. This strategic change towards a diversification of skills is not only based on the changing labour

\footnotetext{
${ }^{4}$ Official ILO statistics exclude migrant workers residing in company accommodation, the majority of them doing lowskilled work.
} 
demand in CoDs, but also on the increasing competition between labour migrants from different countries and the realisation that skills can maximise the benefits of migration for countries of origin, through general upskilling of society, social and financial remittances and return migration (World Bank, 2018b).

Pre-departure skills development programmes in $\mathrm{CoOs}$ are often not valued or required by employers and recruiters in the GCC countries, however, which limits their impact. The skills training offered in technical education centres in Bangladesh, for example, is perceived by foreign employers as being of low quality, not matched with employers' demand and therefore not providing employers a strong signal on the GCC labour market (World Bank, 2018b).

There are also immediate impacts on CoOs as intensive emigration from certain sectors may create labour shortages. The health care sector is one where shortages are typical, and from which many trained workers from Bangladesh, Indonesia and the Philippines generally find work in GCC countries (Yeates and Pillinger, 2018). In 2019, 17000 nurses from the Philippines signed overseas work contracts (Aljazeera, 2020). In fact, Southeast Asian countries face the largest shortage of health workers in the world according to the global threshold of at least 4.45 skilled health workers per 1000 people (WHO, 2016). Shortages lead to reduction in services provided and poorer quality, especially since those who leave generally have high levels of training, experience, and skills (Castro-Palaganas et al., 2017). There have been attempts at minimising such negative effects related to migration. Early in the COVID-19 pandemic, the government of the Philippines banned deployment of healthcare workers; but the ban was eventually lifted and replaced with a cap of 5000 healthcare workers permitted to emigrate per year (Aljazeera, 2020).

\section{What anticipated changes are expected in the GCC migrant labour force?}

The shift to a more capital-intensive economy, recent policies on admission and the long-term effects of the Covid-19 pandemic will change the profile of the GCC migrant labour force.

The on-going change in the GCC employment landscape will affect the prospects for migrant labour. As they are highly over-represented in lower skilled occupations, foreign workers are more exposed to the fallout of automation than nationals (Aus dem Moore et al., 2018). As GCC economies develop sectors where high-skilled labour is more in demand, a shift away from the lower wage and lower skilled foreign worker profile is anticipated. The successful transition of migrants into capital-intensive sectors will largely depend on their ability to acquire adequate skills, and will likely imply a shift in the typical migrant profile working in GCC countries.

Policy plays an important role in the changing migrant profile in GCC countries. In an effort to address youth unemployment, workforce nationalisation policies have gradually been implemented by GCC member states, aiming at generating opportunities for (young) citizens already in or entering the private sector labour market (Peck, 2017). Instruments have included labour market reforms, such as quotas for nationals, restrictive visa policies and sanctions for non-compliance (Alsahi, 2020). The attempt to increase the capacity of the private sector to absorb the new workforce is notable in the strategic development plans of GCC economies. An objective for Oman, for instance, is that $40 \%$ of all new jobs created in the private sector be filled by Omanis, compared to the approximate $12 \%$ rate it was in 2016 (Government of Oman, 2018). Since 2018, Oman only allows the hiring of nationals in certain sectors including information technology, engineering and aviation (Gupta, 2021). In 2021, Oman also announced higher visa fees for employers hiring foreign workers, using the tax to finance vocational training for citizens (Nagraj, 2021).

The COVID-19 pandemic, and the resulting current and future economic contraction, has intensified efforts to tighten rules on migrant admission. Some GCC countries have announced that they would stop issuing or renewing work permits for certain groups of migrants, based on their age or sector of work. Others have 
passed laws allowing employers affected by the crisis to terminate migrant workers' contracts. These policies will likely have long-lasting effects on labour migration in the region (Alsahi, 2020). 


\section{What are the skills of the future in the Abu Dhabi Dialogue area?}

The migration landscape in the ADD area will be disrupted by a changing employment landscape and demand in skills. But what skills will be in demand? There is little doubt that the demand for skills related to new technologies will continue rising in the ADD area, but so will the demand for hard to define soft skills.

The demand for specific technology-relevant skills will be built on STEM and ICT fields, like computer programming, the ability to handle and manage hardware and network infrastructure, and data management. STEM subjects equip people with the problem-solving skills and technical knowledge necessary to understand and work with the ever-changing technologies that will characterise the future in any sector (British Council, 2018).

In light of the changes and the rise in demand for digital and STEM skills in ADD hosting countries, measures have been taken to attract students into related disciplines. The UAE, for example, actively encourages youth to shift away from studying business and finance, typically seen as preparation for government jobs and move toward STEM skills, especially engineering (British Council, 2018). The UAE fostered such change with various strategic measures to spark reforms in its education system. Spurred by its 2015 National Innovation Strategy, the UAE launched several initiatives to attract students toward STEM education, such as the Mohammed bin Rashid SMART Learning Program, the Think Science programme and EmiratesSkills. EmiratesSkills, for example, is a national competition encouraging students to embrace technology-based careers trough vocational training (UAE Ministry of Cabinet Affairs, 2015). The UAE's Fourth Industrial Revolution Strategy, launched in 2017, focuses on research in advanced sciences and artificial intelligence. Motivating youth to enrol in these key fields is a top priority of the UAE to foster a knowledge-based economy (AI Murshidi, 2019). Research and development, product design and marketing skills are also expected to grow in importance in the next years, mostly in the manufacturing, energy as well as technology, media and communications (TMC) sectors (British Council, 2018).

Evidence also points to an awareness of the importance and demand for such skills, including in sending countries. Surveys conducted with TVET institutions from the secondary to the tertiary level in Indonesia, the Philippines and Viet Nam show that institutions have a good understanding of the skills required by the "fourth industrial revolution", but that mismatches in prospects by students remain. In the Philippines, categories of skills for the future identified by training institutions are similar to those seeked by employers, namely technical skills, closely followed by digital and ICT skills, complex problem-solving skills and computer literacy. Nevertheless, assessments of skills and competences differed between training institutions and employers: 96\% of TVET institutions in Indonesia believed their graduates were well prepared for entry-level positions in the labour market, whereas only $32 \%$ of employers in the food and beverage manufacturing and automotive manufacturing sectors thought so (ADB, 2021). 


\section{There is more emphasis on specific tasks and hard to define soft skills}

New technologies will increase the demand for complex tasks and tasks performed in unstructured environments (ADB, 2018). Tasks that cannot be easily automated yet include perception, manipulation, creative intelligence, and social intelligence, notably tasks involving negotiation, persuasion and care (Frey and Osborne, 2017). High-skilled jobs are therefore considered to be complemented by technologicallyinduced automation (Aus dem Moore et al., 2018)."

The decrease of routine tasks will free up workers to focus on tasks that are more complex. Time saved by not having to search through documents for data and information, for instance, will allow workers to spend more time on high-value tasks like critical thinking, coaching others, connecting with people, developing new strategies and creating action plans (De San José, 2019). As Al enters more workplaces, leaders, organisations and workers will need to constantly reinvent their tasks and anticipate opportunities for technologies to enhance human capabilities (Boudreau, 2020).

The greater focus on specific tasks has also shifted attention towards soft skills, as they provide human workers a comparative and complementary advantage over robots. Surveyed for a report on the future of skills in the Asia-Pacific region, 57\% of Learning and Development (L\&D) professionals thought soft skills were more important than technical skills for career progression as they represent a unique human talent in the face of automation and help employees adjust and retrain to keep their roles (Linkedln, 2019b).

In the context of automation, robot-oriented services and Al, people-to-people services may come at a higher premium and therefore reinforce the importance of interpersonal skills. In ICT occupations, skills like analytical thinking, the ability to learn, problem-solving, flexibility, communication, creative thinking, teamwork and leadership are increasingly necessary. Future employment requires the capacity to adapt quickly and interdisciplinary skills are an asset (ILO, 2020). In the event of important technological changes replacing workers and rendering certain skills obsolete, the ability to cope with change and learn new skills will determine whether workers are able to remain employed with new tasks or job (ILO, 2018). Language skills, especially English, are among the most-demanded soft skills (British Council, 2018).

New demand for soft skills is expected to arise in occupations that were formerly mostly technical. Analytical thinking and innovation, active learning, problem-solving, critical thinking and creativity are listed as the top five skills for 2025 in the Future of Jobs Report 2020 (WEF, 2020). Creative and interpersonal skills will be in greatest demand in sectors such as sales, human resources, healthcare and education. Healthcare workers, for instance, might see a redefinition of their roles towards the translation and communication of data produced by new technologies that allow for the automation of diagnosis and personalisation of treatments. In sales jobs, creativity will be essential as traditional retail faces important online competition from e-commerce (WEF, 2016).

Soft skills are however hard to quantify and there is no one-size-fits-all method of acquiring them. While soft skills are largely demanded by employers, the 2019 Global Talent Trends Report notes that $57 \%$ of the companies surveyed struggle to assess soft skills accurately. The lack of a clear formal process to quantify such skills means assessments are often based on perceptions behaviour as well as body language, which are often unconsciously biased (Linkedln, 2019a). Suggestions on how to teach such skills underline that people must first develop specialised expertise before acquiring general skills like problem-solving. In other words, "generic skills are often best acquired in the context of mastering specific disciplinary, trade or professional expertise" (ILO, 2018). In light of this, TVET institutions in Singapore, for example, have moved away from conventional workshops and laboratories to create learning facilities that model actual workplace settings where students can pick up the soft skills necessary in a specific profession (Tan and Seet, 2020). 
How ready are countries of origin for the change in employment landscape in the Abu Dhabi Dialogue area?

The economies in ADD CoOs currently heavily depend on the agricultural sector, although a transition toward more capital-intensive sectors is under way. In general, terms, the agriculture, forestry and fishing industries continued to be the main sector of employment in 2019, with shares over total employment varying from a low of $23 \%$ in the Philippines to a high of $64 \%$ in Nepal. The share of employment in the agricultural sector has significantly reduced since 2000 in CoOs, however, accompanied by a rise of employment in the manufacturing, construction, transport as well as wholesale and retail trade sectors. This is led by Pakistan, Sri Lanka and Viet Nam where approximately $18 \%$ of the respective populations were working in the manufacturing industry in 2019. The manufacturing sector is the second largest sector of employemnt in most countries with the exceptions of Afghanistan, Indonesia and the Philippines, where more people are employed in wholesale and retail trade (Figure 4).

Figure 4. Employment distribution by economic activity in ADD countries of origin $(\%, 2000,2010$, 2019)

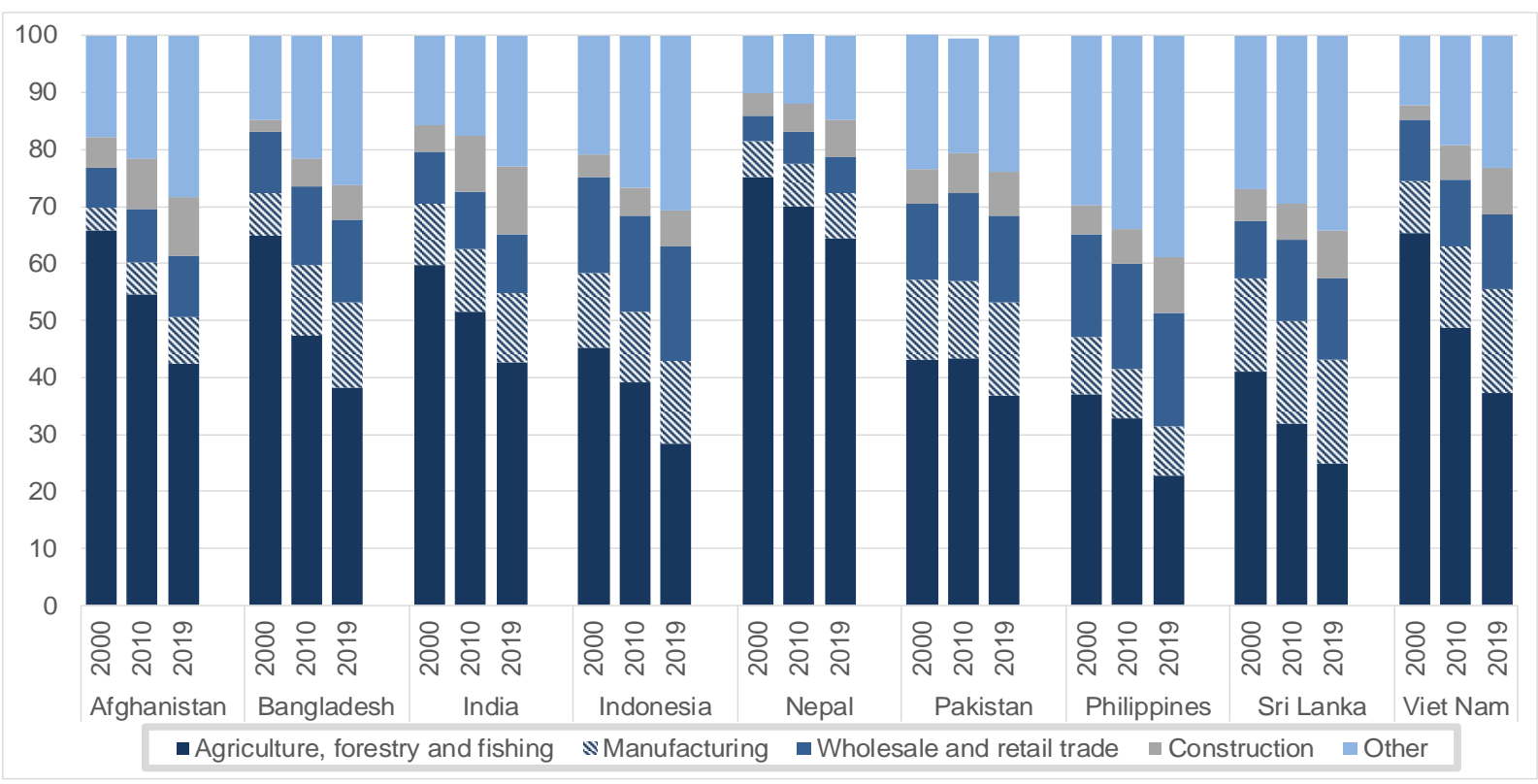

Note: Other includes education, health, transport; accommodation \& foodservices; financial and insurance activities; real estate; entertainment; private households with employed persons; mining and quarrying; and utilities.

Source: ILO STAT (2020a), ILO modelled estimates,

www.ilo.org/shinyapps/bulkexplorer16/?lang=en\&segment=indicator\&id=EMP_2EMP_SEX_ECO_DT_A, accessed in February 2021.

A large share of the labour force in CoOs has no formal schooling, although the share has been decreasing across all countries. Individuals with no formal schooling form the majority of workers in Afghanistan, Bangladesh, Nepal and Pakistan, translating to a large share of the population working in low-skilled jobs. Comparing the average educational distribution of the workforce versus that of youth aged 15 to 24 suggests an increasingly educated population. In 2017, for example, $22 \%$ of the workforce in Nepal had completed upper secondary level whereas this proportion was 34\% for younger co-horts (ILO Stat, 2017).

The "fourth industrial revolution" is expected to generate an important displacement of workers in CoOs that will likely lack the necessary skills to transition easily to new employment opportunities. In Viet Nam's agro-processing sector for example, it is estimated that approximately $33 \%$ of the workforce will be displaced by 2030 , as their tasks will become automated. However, job reductions in the agro-processing 
sector would be counterbalanced by a $68 \%$ increase in labour demand spurred by revenue increases based on technology-related productivity gains, leaving a net impact on jobs in this sector to a positive of $34 \%$. In most sectors, job lost will be offset by job creation due to this 'productivity effect', but skills development is essential for people to transition in these new jobs that may require different skills (ADB, 2021).

As CoOs are also facing higher demand in new technology-related fields in their own countries, they also face the threat of skill shortages. A recent survey found that the availability of adequate digital skills in the workforce is a concern for $80 \%$ of business CEOs globally (PwC, 2017a). In South and Southeast Asia, the skills shortage in STEM fields is in fact higher than the global average (45\% versus $28 \%)($ ILO, 2018). The Federation of Indian Chambers of Commerce and Industry estimates that around $60 \%$ to $70 \%$ of the ICT workforce will need reskilling or retraining in sectors such as biotechnology, nanotechnology, selfmonitoring analysis and reporting technology (SMART), and advanced analysis. Evidence also points to shortages of ICT specialists with master degrees and above, and positions such as web developers (especially Android developers), programmers and graphic designers being the most difficult to fill in Indonesia. In Thailand, evidence suggests shortages in both high-skilled and semi-skilled ICT positions (ILO, 2019).

\section{Reimagining labour markets and education systems for $21^{\text {st }}$ century skills}

Equipped with new skills, students and workers in CoOs can obtain higher-skilled jobs and improve their employment outcomes. The distributional effects of digitalisation suggest that highly skilled workers benefit more from digitalisation, as they tend to perform tasks that are complementary with technology (OECD, 2021a). Enrolment rates in tertiary education have increased since 2000, but the speed of this transformation has varied across countries. Indonesia, the Philippines, India and Viet Nam have the highest university graduation rates in the region, while enrolment in tertiary education remains low in Afghanistan, Bangladesh, Nepal, Pakistan and Sri Lanka (Figure 5). Moreover, among graduates, the share of people graduating from STEM-related programmes is $23 \%$ in Viet Nam, $32 \%$ in India, $19 \%$ in Indonesia and 29\% in the Philippines (World Bank, 2021b). ${ }^{5}$ Apart from the Bangladesh (11\%), these rates are similar to those in OECD member countries.

Other issues need to be tackled, and which could help further boost graduation from STEM fields. Gender differences in skills remains large in the region for instance. Top-performing girls in the OECD's PISA assessment on science and mathematics across four Southeast Asian countries are half as likely as boys to aspire to a career in science and engineering. Across OECD countries, the difference between girls and boys is 11 percentage points (OECD, 2021b).

The lack of complex soft and IT skills in the workforce is anticipated to also produce skill mismatches. Skill mismatches are defined as the gap between the skills of redundant workers and the skills needed in vacant positions. By 2028, it is estimated that skill mismatch will reach $14 \%$ in the Philippines, $13 \%$ in Viet Nam and $8 \%$ in Indonesia, with deficiencies in skills such as negotiation, persuasion and service orientation impeding the move of employees to newly created opportunities (Cisco and Oxford Economics, 2018).

A major gap on soft skills is related to data. Data on soft skills among the population in South and Southeast Asian countries is lacking. Studies suggest that both employers and employees in Asia are however increasingly aware of the importance of soft skills in addition to technical skills (Ernst \& Young India, 2019). A 2019 Linkedln survey, for example, reported that in India, 45\% of employees had left a company because there were insufficient learning and development opportunities, which highlights the value placed on acquiring new skills (Linkedln, 2019b).

\footnotetext{
5 The latest year for which data is available differs between countries and ranges from 2016 to 2019. Data is unavailable for Afghanistan, Nepal, Pakistan and Sri Lanka.
} 
Figure 5. Gross school enrolment at tertiary level in ADD countries of origin (\%)

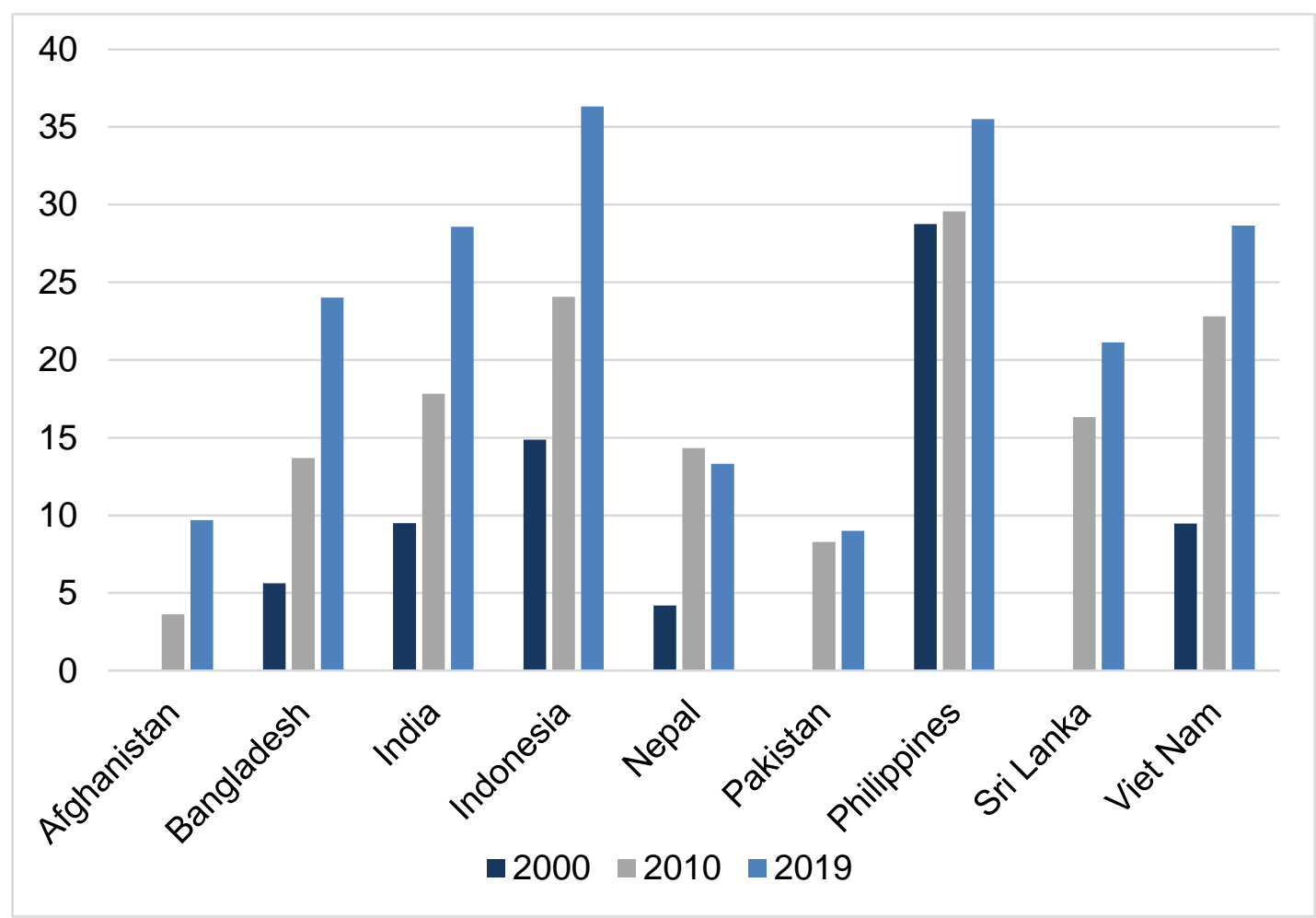

Note: The latest year for which this data was available differs between countries: 2000 [PHL 1999]; 2010 [AFG 2011, BGD 2011, PAK 2011]; 2019 [AFG 2018, IDN 2018, PAK 2018, PHL 2017, THA 2016].

Source: World Bank (2021c), World Development Indicators,

https://databank.worldbank.org/reports.aspx? source=2\&series=SE.TER.ENRR\&country=PHL,AFG,KHM,BGD,CHN,IND,IDN,PAK,LKA,THA,V NM,NPL, accessed in February 2021.

\section{Adapting strategies for the future of (migrant) labour demand}

Strategies to leverage the potential of digital technologies are fundamental to navigate the ongoing changes. Recent strategies in India, Indonesia, the Philippines and Viet Nam aim at adopting advanced technologies in strategic industrial sectors, and such efforts have accelerated since the COVID-19 pandemic began (OECD, 2021a). Many challenges remain, ranging from lack of digital awareness, shortages in skilled labour, limited budgets, inadequate infrastructure and weak cybersecurity (OECD, 2021a).

Viet Nam stands out as for its readiness and adaptability in linking education and training curricula with emerging skills needs. Its National Strategy on Fourth Industrial Revolution outlines a series of policies aiming to adjust educational curricula, including vocational training. The strategy notably includes a strong focus on soft skills such as language and communication skills. On the other hand, strategies in Cambodia, Indonesia and the Philippines were found to be too rigid in curricula (ADB, 2021).

In an effort to address rigidity in its educational system, the Philippines established a nationwide mapping of $21^{\text {st }}$ century skills through consultations with employers to identify emerging skills needs and gaps in the workforce skill set. The Philippines' National Technical Education and Skills Development Plan also considers the impacts of the 'fourth industrial revolution' on jobs and skills (ADB, 2021). In India, a competency-based National Skills Qualifications Framework (NSQF) has also been developed, curating 
occupational standards for developing future skills in line with emerging job market needs. The standards are regularly updated to include emerging skills (Khan and Sharma, 2021).

Despite the growth of interest in STEM-related education fields, one area of particular concern across the region is in technical and vocational education and training (TVET), where enrolment remains low, particularly in ADD CoOs. TVET programmes are generally viewed across society as second-class and less prestigious, which explains why other more general education programmes are preferred. Compared to Finland and the United Kingdom, for example, where the share of secondary level students enrolled in vocational training was above $45 \%$ in 2016, most emerging Asian countries have low enrolment. The share in the Philippines, for example, was about $6 \%$ in 2017 , and in India, less than $2 \%$. A notable exception is Indonesia, where the rate of students enrolled in vocational training is nearly $20 \%$, following reform in the country's TVET system, which aimed to ensure a better linkage with the skills demanded in the labour market. Around $56 \%$ of Indonesian vocational secondary schools focus on ICT and about $46 \%$ on technology and engineering (OECD, 2019a).

TVET provides practical and industry-specific training. In the GCC region, TVET has been specifically relevant for jobs in the technology and hospitality sectors. However, major gaps also exist in the skills developed and skills in demand - and the gap is widening as technologies, and industrial processes evolve. A 2014 survey conducted by Ernst and Young with 100 firms and 1000 students in the GCC region found that there were major gaps between the skills being taught and those that are in demand by employers, noting that only $16 \%$ of employers felt that the specific skills required by their industry were being taught to students. Establishing a perspective where vocational training is viewed as equally rewarding as academic paths will be an important step in establishing a better linkage between skills taught and in demand (Ernst \& Young, 2015). In fact, the importance of establishing a greater vocational training culture has been acknowledged by many GCC economies. The UAE government's online TVET portal notes that the UAE will need to produce ten workers with vocational skills for every university graduate to achieve its objective of a sustainable and diversified knowledge-based economy. ${ }^{6}$

The low rates of TVET enrolment are concerning since demand is slated to increase in sectors needing such skills. A promising area of growth in the region in is access and use of the internet, which provides room for self- or online learning. General internet usage equips people with new skills and opportunities, outside of the formal educational system. Internet-use rates are particularly high in Viet Nam (70\%) and the Philippines (60\%), and growing in Indonesia (40\%), Sri Lanka (34\%) and India (32\%). They remain relatively low, however, in Nepal (21\%), Bangladesh (18\%), Pakistan (17\%) and Afghanistan (11\%) (Figure 6). The average usage across CoOs remains lower than in OECD countries (83\%) and GCC countries (whose rates rage from $80 \%$ to $99 \%$ ) (World Bank, 2018c). Additionally, women have less access and make less use of digital technologies. In 2017, the internet user gender gap was estimated at $17 \%$ in the Asia and Pacific region (ITU, 2017).

\footnotetext{
${ }^{6}$ The UAE governmental TVET portal: https://u.ae/en/information-and-services/education/technical-and-vocationaleducation.
} 
Figure 6. Individuals using the Internet in ADD countries of origin (\% of population)

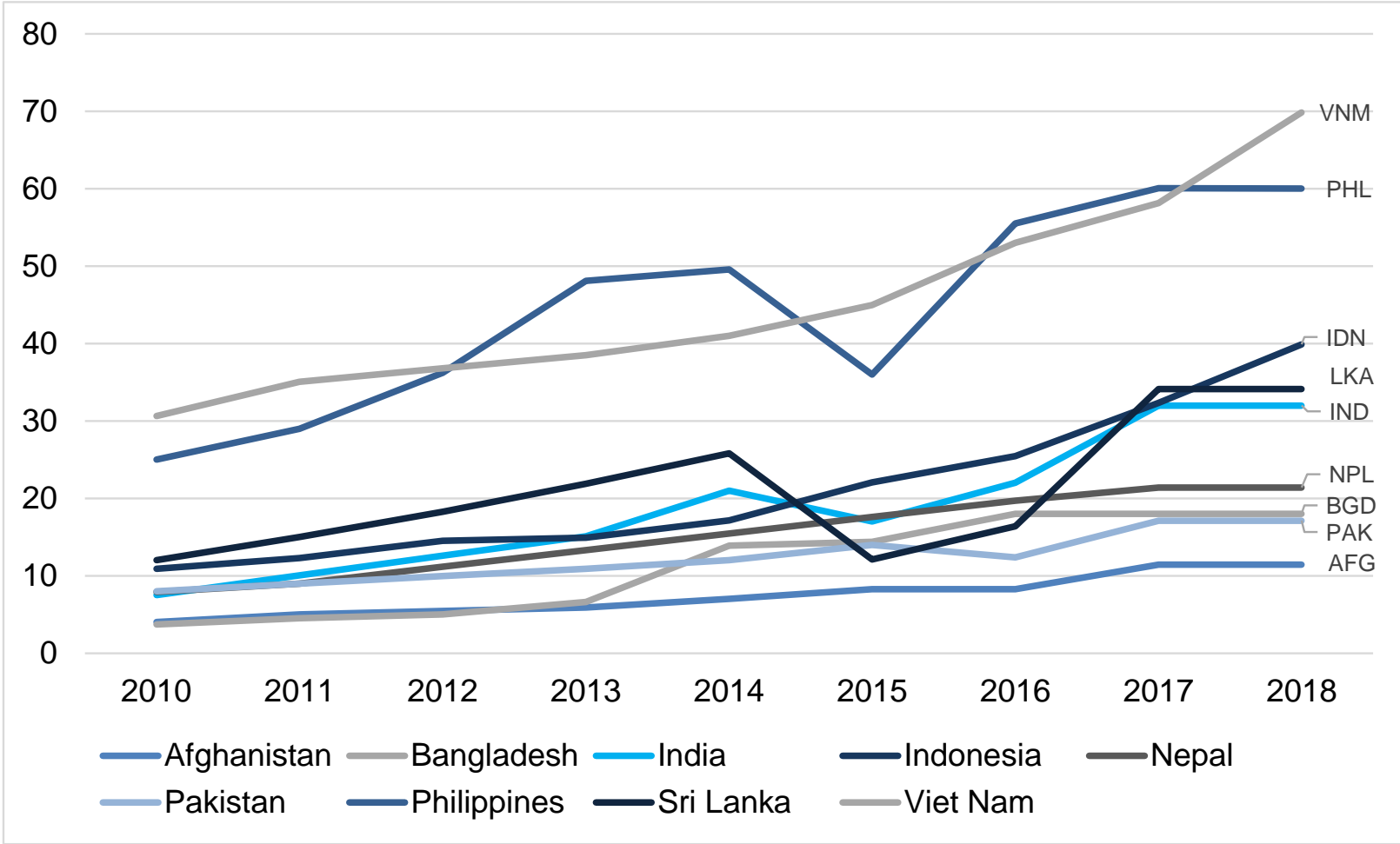

Source: World Bank (2018c), World Development Indicators,

https://databank.worldbank.org/reports.aspx?source=2\&series=IT.NET.USER.ZS\&country=AFG,BGD,IND,IDN,NPL,PAK,PHL,LKA,VNM, accessed in March 2021. 


\section{How can countries adapt to changing labour migration needs?}

Future technology-driven ecosystems will require advanced logistics, high-speed internet connectivity and sophisticated infrastructure, but also specialised skills (OECD, 2018b). The transition to knowledge-based economies will depend on the ability of countries to develop and leverage human capital, so that workers are more productive and technologically well equipped. Indeed, the future of employment implies the 'reconstruction of work' in a way that optimises the combination of human tasks and machine tasks (Boudreau, 2016). Adapting migrant recruitment systems will also be key in ensuring that changes in the demand for skills are taken into account in the readiness of potential migrants.

Technological innovations will affect countries and workers differently, requiring differentiated skill development programmes. Workers who lose their jobs will likely need to retrain, learn new skills and potentially shift to new sectors. Others will experience changes in the tasks they are asked to perform and will need to upgrade certain skills, through short-term or on-the-job trainings. Future workers who join the labour market will need to be prepared with adequate skills in their education journey (ADB, 2021).

Education systems in GCC countries mostly focus on credentials rather than skills demanded by private sector employers. In the public sector, where citizens commonly find employment, obtaining credentials - a diploma, a degree or a certificate - has been emphasised more than acquiring skills. Consequently, memorisation, rather than critical thinking, problem-solving, collaborative teamwork, and socioemotional and digital skills, features prominently in school curricula in GCC countries (El-Saharty et al. 2020). A modernisation of the educational curriculum, from credentials to skills, from schooling to learning, is needed to have an education system that focuses on competencies needed in the new economy. This is especially the case for vocational and technical education, and higher education. As an example, Finland has notably implemented such a reform to promote twenty-first century transversal competences as well as life-long and life-wide learning. The Finnish curriculum includes a focus on language and digital skills and uses collaborative classroom practices to engage students (Lavonen, 2020).

Global competition for high-skilled migrant workers has also increased with digitalisation (OECD, 2016). The OECD Skills Outlook 2019 shows a growing demand for different positions that require digital skills such as software and applications developers, database and network professionals and ICT operations technicians (OECD, 2019b). Due to high labour demand and skills shortages in ICT sectors, several countries, like Canada, China and Germany, have implemented favourable visa policies to attract workers with digital skills. India is a large supplier of ICT workers and recent graduates, who typically obtain jobs in the United States, the United Kingdom and European countries (ILO, 2020). GCC countries will face increased competition to attract workers with the right skills for their developing technology-intensive sectors.

Enabling women to benefit from the shift in the changing demand for skills will also be fundamental. Indeed, at the university level, women in GCC countries make up more than $50 \%$ of enrolled students in Science, Technology, Engineering and Math (STEM) fields. Enrolment of women especially outnumbers that of men in Natural sciences, Math and Statistics programmes, accounting from $57 \%$ of students in the UAE to $85 \%$ of students in Bahrain. Women are also more numerous than men in ICT programmes in Oman, Qatar and 
the UAE, although closer to a $50 \%$ share (Islam, 2019). The rise of digital jobs present opportunities for women as they offer benefits like flexibility and project-based work models (PwC, 2017b).

As ADD countries develop the human capital of their populations, labour migration systems need to be able to recognise, evaluate and target skills in demand. Migration recruitment systems are also key in advancing 'fourth industrial revolution' skills, by acting as bridges between sending and receiving economies. Regional Model Competency Standards (RMCS) could facilitate the assessment and the recognition of migrant workers' skills. Such standards would define the skills required in a specific sector and provide a flexible framework that firms could customise and use in different countries to suit different skills recognition systems (ILO, 2014a). A rethinking of pre-departure orientation trainings may ensure their relevance, for instance, in the context of increasing use of new technologies.

Developing bilateral and regional partnerships, built on skills and benefits for both CoOs and CoDs, will be key. Labour shortages combined with the prospects of outward migration raise the risk of brain drain for CoOs. To minimise the negative consequences, ADD member countries can draw upon experiences like the 'Project Addressing Labour Shortages Through Innovative Labour Migration Models' (PALIM) programme, implemented in 2019 by Enabel - Belgium's development agency - in partnership with the Belgian region of Flanders and Morocco. This skills partnership trains ICT workers in Morocco in order to respond to labour shortages and skills mismatch in this sector in both Flanders and Morocco. In this agreement, half the trainees find skilled jobs in their country, while the other half migrate to Belgium, which benefit both $\mathrm{CoO}$ and $\mathrm{CoD}$ (Enabel, 2019).

Each corridor has its own specificities, cultures, expectations and ultimately uniqueness. And while principles may be distilled from the growing body of good practices across the world, an organic and genuine process is necessary to build a sustainable regional dialogue on migration. A change in the outlook and strategy for the future of employment will require a greater territorial approach to policies linking migration and development, a more active engagement with local governments, but also a better understanding of youth and how young migrants, specifically, integrate into host countries, and in return, contribute to the development of their home countries. Development strategies are increasingly accounting for the change in global industrial processes, but few account for its impact on global labour mobility. As development strategies adjust to these changes, they must also account for the new skills demand they entail, and in turn the impact this has on labour migration, translating into concrete policy action in both countries of origin and destination. As technologies, skills and sectors evolve, a continuous revisiting and reimagining of development strategies is essential (Figure 7). 
Figure 7. Development strategies need to be continuously updated in the light of skills-related changes to benefit both sending and receiving countries

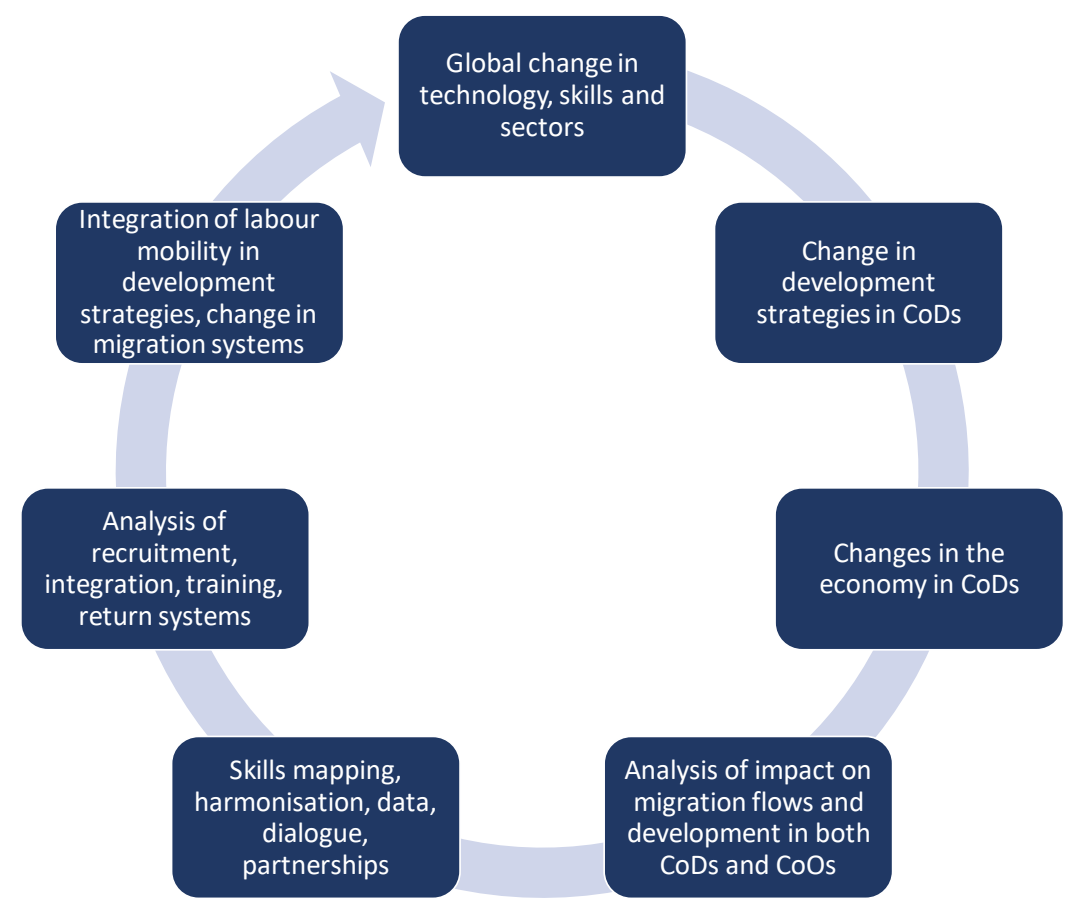

Source: Authors' elaboration.

\section{What is the role of regional consultative processes on migration in preparing for the future demand in skills?}

The GCC labour market is in flux and the ADD will play a crucial role in creating dialogue, particularly around the issues of credential certification, migration partnerships based on skills development in both $\mathrm{CoOs}$ and CoDs, data sharing and bringing education and employment sectors closer together. GCC countries are actively seeking to move to higher value technology sectors, which will have a direct effect on the existing migration mechanisms on which both GCC countries and South and Southeast Asian countries are dependent. CoOs have been transitioning to higher-tech sectors, but at a slower pace than their CoDs counterparts have. Thus, there will likely continue to be a disparity of economic opportunities between ADD countries, and therefore demand for migration.

Here are therefore five areas in which the ADD's role will be pivotal in establishing partnerships and solidifying a smooth and resilient future of labour in both CoOs and CoDs :

\section{Map and harmonise skills development programs in countries of origin with labour demand in countries of destination}

The future of employment will affect the supply and demand of skills. Good preparation will require mapping exercises from several angles - understanding what skills exist in both CoOs and CoDs, but also what employers in CODs are and will be demanding in the future. Not only will CoOs need to develop skills portfolios and mapping of workers in their own countries, in coherence with ambitions and plans in CoDs, but such programmes will also need to determine and define such skills, beyond those that are already well-known and defined today, and elaborate a plan to evaluate them. The ADD can then foster an areawide strategy to incentivise students and older workers to gain skills in demand in the future, target specific 
groups, such as women and help develop a culture of life-long learning amongst both employers and employees.

\section{Implement migration mechanisms that ensure the recognition of existing education credentials by employers in countries of destination}

In addition to mapping and harmonising skills programmes, the ADD has a role in ensuring that credentials certifying general education or Technical and Vocational Education and Training (TVET) are recognised by foreign employers in CoDs - fundamental in laying the groundwork for a smooth transition of migration systems into the future of work landscape. Implementing mechanisms to recognise and value the skills acquired by migrant workers in their CoOs can incentivise governments to invest more in development programs, as well as facilitate upskilling by migrants themselves, which will also benefit CoDs by filling skilled labour gaps. Such mechanisms should be implemented directly in national development strategies, as well as strategies explicitly pertaining to migration. An important element in skills recognition will be the definition of soft skills in demand in the future.

\section{Create skills partnerships that benefit both countries of origin and of destination}

Higher demand for skills in the future may generate competition for skilled migrant workers. Both CoOs and CoDs can gain from labour migration by establishing partnerships to fill labour gaps on both sides. To minimise potential negative consequences of high-skilled migration and retain skilled workers in CoOs, member countries can develop partnerships to train workers with specific skills in CoOs in order to respond to labour shortages and skills mismatch in a specific sector in both CoOs and CoDs. Such partnerships can leverage lessons learned from existing programmes in other parts of the world, including the PALIM programme between Belgium and Morocco targeting ICT workers.

\section{Spur dialogue between educational institutions and employers at the national level}

Alignment between education and training institutions with the private sector, on issues such as critical skills required by the 'fourth industrial revolution', the relevance of educational and training curricula, and skills certification systems will be key to adapting the shift in skills demand. More collaboration and coordination between educational institutions and employers is needed in the ADD area in order to reduce existing and potential future gaps in skills, including ill-defined soft skills. Employers will need to be more integrated in the education cycle, integrating apprenticeships and life-long learning concepts, within and between CoOs and CoDs.

\section{Enhance and encourage data sharing across ADD member states}

The ability to effectively navigate the future of work landscape and the shifting demand in skills in the ADD area will be enhanced with access to the right data and harmonising evidence-based planning. Better data sharing and harmonisation can help minimise skills shortages and mismatches in both CoOs and CoDs. As such, the ADD's role in creating platforms for better data sharing not only between employers and education institutions, but also between line ministries, private sector, civil society and local governments across different countries on key indicators of the future of work landscape will be essential. 


\section{Annex A. Strategic Development Plans in Gulf Cooperation Council countries}

\begin{tabular}{|c|c|c|c|}
\hline Country & Name of the strategy & Year of publication & Authority responsible \\
\hline Bahrain & $\begin{array}{c}\text { Economic Vision } 2030 \text { for } \\
\text { Bahrain }\end{array}$ & 2008 & $\begin{array}{l}\text { Economic development } \\
\text { Board chaired by His Royal } \\
\text { Highness Prince Salman } \\
\text { Bin Hamad Al Khalifa }\end{array}$ \\
\hline Kuwait & New Kuwait Vision 2035 & $\begin{array}{l}2017 \\
\text { [A previous one was } \\
\text { launched in } 2010 \text { also with } \\
\text { the } 2035 \text { horizon] }\end{array}$ & $\begin{array}{l}\text { His Highness the Emir of } \\
\text { Kuwait Sheikh Nawaf Al- } \\
\text { Ahmad Al-Jaber Al-Sabah }\end{array}$ \\
\hline Oman & Oman Vision 2040 & 2018 & $\begin{array}{c}\text { Oman } 2040 \text { Main } \\
\text { committee under royal } \\
\text { directives from His Majesty } \\
\text { Sultan Haitham bin Tarik }\end{array}$ \\
\hline Qatar & Qatar National Vision 2030 & 2008 & $\begin{array}{l}\text { General Secretariat for } \\
\text { Development Planning with } \\
\text { the guidance of Qatar's } \\
\text { Higher Authorities }\end{array}$ \\
\hline Kingdom of Saudi Arabia & $\begin{array}{l}\text { Kingdom of Saudi Arabia } \\
\text { Vision } 2030\end{array}$ & 2016 & $\begin{array}{l}\text { Council of Economic and } \\
\text { Development Affairs } \\
\text { chaired by His Royal } \\
\text { Highness Prince } \\
\text { Mohammed bin Salman bin } \\
\text { Abdulaziz }\end{array}$ \\
\hline United Arab Emirates & $\begin{array}{c}\text { United Arab Emirates } \\
\text { Vision } 2021\end{array}$ & 2010 & $\begin{array}{c}\text { His Highness Sheikh } \\
\text { Mohammed bin Rashid Al } \\
\text { Maktoum }\end{array}$ \\
\hline
\end{tabular}




\section{Annex B. Pre-departure orientation and skilling strategies for migrant workers, by Abu Dhabi Dialogue country of origin}

\begin{tabular}{|c|c|c|c|}
\hline $\begin{array}{l}\text { Countries of } \\
\text { origin }\end{array}$ & Pre-departure orientation (PDO) & Skilling strategies & $\begin{array}{l}\text { Overarching institution } \\
\text { and partners }\end{array}$ \\
\hline Afghanistan & $\begin{array}{l}\text { Pre-departure training is the } \\
\text { responsibility of recruitment } \\
\text { agencies. No enforcement } \\
\text { mechanisms are in place } \\
\text { (Holzmann, 2018). } \\
\text { Duration: n/a. }\end{array}$ & $\mathrm{n} / \mathrm{a}$ & $\begin{array}{l}\text { Ministry of Labour, } \\
\text { Social Affairs, Martyrs, } \\
\text { and the Disabled - } \\
\text { Overseas Employment } \\
\text { Unit (OEU) }\end{array}$ \\
\hline Bangladesh & $\begin{array}{l}\text { Country-specific PDOs are } \\
\text { organised on working environment } \\
\text { and culture in CoDs, salary, } \\
\text { remittance system, services, } \\
\text { conditions, religious practices and } \\
\text { basic language training. } \\
\text { Duration: one day at most (World } \\
\text { Bank, 2018b). }\end{array}$ & $\begin{array}{l}\text { Since 2011, overseas employment } \\
\text { is part of the national development } \\
\text { strategy, with a focus on increasing } \\
\text { the skills of overseas workers } \\
\text { (upskilling). The strategies (2011, } \\
\text { 2016) focus on sending semi-skilled } \\
\text { and skilled workers abroad to adapt } \\
\text { to the diversification of the foreign } \\
\text { labour markets. The BMET provides } \\
\text { training in Technical training } \\
\text { centres, for sectors including } \\
\text { domestic work, construction and } \\
\text { trade, mechanics, computer } \\
\text { operation, electrical maintenance, } \\
\text { etc. Some of them are available } \\
\text { online (Reza et al., 2018). }\end{array}$ & $\begin{array}{c}\text { Ministry of Expatriates' } \\
\text { Welfare and Overseas } \\
\text { Employment - Bureau } \\
\text { of Manpower, } \\
\text { Employment and } \\
\text { Training (BMET) }\end{array}$ \\
\hline India & $\begin{array}{l}\text { PDO includes ten modules covering } \\
\text { the costs and benefits associated } \\
\text { with migration, recruitment process, } \\
\text { entry formalities, labour laws in } \\
\text { CoDs, remittances, terms of } \\
\text { contract, working conditions, socio- } \\
\text { cultural and religious aspects, and } \\
\text { language. With a focus on } \\
\text { GCC countries and Malaysia, PDO } \\
\text { trainings also outline the welfare } \\
\text { schemes of the Indian Government, } \\
\text { the helplines, and the role of Indian } \\
\text { missions abroad in addressing the } \\
\text { grievances of workers. } \\
\text { Duration: } 5 \text { days (Bhaskar, 2017). }\end{array}$ & $\begin{array}{l}\text { Government funded skill } \\
\text { development programmes such as } \\
\text { Pravasi Kaushal Vikas Yojana } \\
\text { (PKVY) are available to migrant } \\
\text { workers. PKVY is a programme } \\
\text { aimed at facilitating overseas } \\
\text { employment opportunities by } \\
\text { enhancing the skill set of potential } \\
\text { emigrants, especially youth, in } \\
\text { specific sectors and jobs that are in } \\
\text { demand in destination countries. } \\
\text { Eight sectors have been identified } \\
\text { namely domestic work; retail; } \\
\text { tourism and hospitality; capital } \\
\text { goods; healthcare; construction; } \\
\text { automotive; and security } \\
\text { (Government of India, 2016). }\end{array}$ & $\begin{array}{l}\text { Ministry of External } \\
\text { Affairs (MEA)- } \\
\text { Overseas Employment } \\
\text { Division } \\
\text { Ministry of Skill } \\
\text { Development and } \\
\text { Entrepreneurship } \\
\text { (MSDE) }\end{array}$ \\
\hline
\end{tabular}




\begin{tabular}{|c|c|c|c|}
\hline Indonesia & $\begin{array}{l}\text { Pre-departure briefings comprise of } \\
\text { four modules: working conditions } \\
\text { and host country's laws, } \\
\text { employment contracts, } \\
\text { psychological concerns and } \\
\text { personality development as well as } \\
\text { drugs and contagious diseases. } \\
\text { Duration: } 8 \text { hours (Yuniarto, 2019). }\end{array}$ & $\begin{array}{l}\text { For migrants leaving to work in } \\
\text { private households, a two-months } \\
\text { training is mandatory to improve } \\
\text { technical skills, understanding of the } \\
\text { working conditions, communication } \\
\text { skills and awareness of rights and } \\
\text { obligations (Patunru and Uddarojat, } \\
\text { 2015). } \\
\text { The } 2017 \text { Law on the protection of } \\
\text { Indonesian migrant workers } \\
\text { provides guidelines for skills } \\
\text { upgrading and enhancing } \\
\text { programmes. These programmes } \\
\text { are available to those with } \\
\text { elementary or junior high school } \\
\text { degrees who have obtained a work } \\
\text { contract with non-household } \\
\text { employers. It aims to prepare } \\
\text { workers to meet the requirements of } \\
\text { overseas employment in terms of } \\
\text { competences (Yuniarto, 2019). }\end{array}$ & $\begin{array}{l}\text { National agency for the } \\
\text { placement and } \\
\text { protection of migrant } \\
\text { workers (BNP2TKI) }\end{array}$ \\
\hline Nepal & $\begin{array}{c}\text { PDO acquaints migrant workers with } \\
\text { the culture, customs, rules and laws } \\
\text { applicable in CoDs, financial literacy } \\
\text { as well as health-related technology } \\
\text { like mobile apps. The fees of this } \\
\text { training are reimbursed for women } \\
\text { migrant workers. } \\
\text { Duration: } 3 \text { days (Government of } \\
\text { Nepal, 2020). }\end{array}$ & $\begin{array}{l}\text { The } 2012 \text { foreign employment policy } \\
\text { states that vocational training and } \\
\text { technical education institutions } \\
\text { provide trainings to migrant workers } \\
\text { to improve their skill composition } \\
\text { and their ability in CoDs languages } \\
\text { (Government of Nepal, 2012). } \\
\text { Since 2011, a bilateral initiative } \\
\text { between the Governments of Nepal } \\
\text { and Switzerland, called Safer } \\
\text { Migration project, offers one-month } \\
\text { pre-departure skills trainings for } \\
\text { migrant workers in the following } \\
\text { trades: garment manufacturing, } \\
\text { masonry, shuttering carpentry, } \\
\text { plumbing, scaffolding, and electricity } \\
\text { work (SaMl, 2021). } \\
\text { Female domestic workers must } \\
\text { complete a mandatory 35-day } \\
\text { training which focuses on soft skills } \\
\text { such as language skills and } \\
\text { domestic work-specific skills such } \\
\text { as cooking and cleaning } \\
\text { (Government of Nepal, 2020). }\end{array}$ & $\begin{array}{l}\text { Ministry of Labour, } \\
\text { Employment and Social } \\
\text { Security (MOLESS) - } \\
\text { Department of Foreign } \\
\text { Employment (DOFE) } \\
\\
\text { Vocational and Skill } \\
\text { Development Training } \\
\text { Academy }\end{array}$ \\
\hline
\end{tabular}




\begin{tabular}{|c|c|c|c|}
\hline Pakistan & $\begin{array}{l}\text { PDO seminars provide information } \\
\text { on life in CoDs, namely on rules and } \\
\text { laws, employment, contractual } \\
\text { arrangements, resources available } \\
\text { in times of difficulty, culture and } \\
\text { finances (wages, compensations in } \\
\text { case of accident). Content and } \\
\text { access to these trainings vary } \\
\text { (World Bank, 2018d). } \\
\text { Duration: } 1-5 \text { days. }\end{array}$ & $\begin{array}{l}\text { The } 2018 \text { National Skills for all } \\
\text { strategy outline Pakistan's } \\
\text { commitment to skills development } \\
\text { for international markets considering } \\
\text { the increasing demand for skilled } \\
\text { labour. Destination specific TVET } \\
\text { (Technical and Vocational } \\
\text { Education and Training) institutes } \\
\text { were implemented for this purpose } \\
\text { (Government of Pakistan, 2018). In } \\
\text { a skill demand assessment for } \\
\text { GCC countries, the TVET authority } \\
\text { of Punjab identified the following } \\
\text { sector as having potential for skilled } \\
\text { Pakistani workers: hospitality; } \\
\text { garments; beautician; information } \\
\text { and communication technology; } \\
\text { micro entrepreneurs; service } \\
\text { (security guards); and health care } \\
\text { (GIZ and ILO, 2016). }\end{array}$ & $\begin{array}{c}\text { Ministry of Overseas } \\
\text { Pakistanis and Human } \\
\text { Resource Development } \\
\text { National Vocational } \\
\text { and Technical Training } \\
\text { Commission }\end{array}$ \\
\hline Philippines & $\begin{array}{l}\text { Country-specific PDO seminars } \\
\text { consist of modules on employment } \\
\text { contract, stages of life in CoDs, } \\
\text { health and safety, financial literacy, } \\
\text { travel tips and government } \\
\text { programmes and services. } \\
\text { A specific PDO seminar is offered } \\
\text { for domestic workers and includes } \\
\text { language training, culture } \\
\text { familiarization and stress } \\
\text { management. } \\
\text { Duration: } 1 \text { day for the regular PDO } \\
\text { and 4-6 days for domestic workers } \\
\text { (Government of the Philippines, } \\
\text { 2021). }\end{array}$ & $\begin{array}{l}\text { Different skills development and } \\
\text { enhancement programmes are } \\
\text { accessible to migrant workers and } \\
\text { their dependents, with a scholarship } \\
\text { from OWWA. The programmes vary } \\
\text { from 6-months vocational courses to } \\
\text { one-year technical courses with the } \\
\text { goal to deploy only skilled Filipino } \\
\text { workers abroad (Government of the } \\
\text { Philippines, 2021). The most } \\
\text { popular TVET trainings are in the } \\
\text { tourism, health services, } \\
\text { manufacturing, construction and } \\
\text { maritime sectors (TESDA, 2018). }\end{array}$ & $\begin{array}{c}\text { Overseas workers } \\
\text { welfare administration } \\
\text { (OWWA) } \\
\text { Technical Education } \\
\text { and Skills Development } \\
\text { Authority (TESDA) }\end{array}$ \\
\hline Sri Lanka & $\begin{array}{c}\text { PDO focuses on discipline and } \\
\text { obligations of the worker, cultural } \\
\text { aspects, travel information, laws and } \\
\text { contract regulations, stress } \\
\text { management and workplace } \\
\text { environment (Government of } \\
\text { Sri Lanka, 2021). } \\
\text { Duration: } 1 \text { day. }\end{array}$ & $\begin{array}{l}\text { A specific } 21 \text {-day skill training for } \\
\text { female domestic worker leaving for } \\
\text { the Middle East must be completed } \\
\text { and includes courses on cleaning } \\
\text { techniques, food preparation, caring } \\
\text { of elders/ patients/ children, first aid } \\
\text { and others (Government of } \\
\text { Sri Lanka, 2021). } \\
\text { The } 2010 \text { National Strategy on } \\
\text { TVET Policy identifies migrant } \\
\text { workers as a vulnerable group and } \\
\text { aim to provide them with TVET } \\
\text { programmes (Government of } \\
\text { Sri Lanka, 2010). Foreign } \\
\text { employment training institutions } \\
\text { focus on the tourism, nursing, } \\
\text { technical and construction sectors } \\
\text { (ADB, 2015). }\end{array}$ & $\begin{array}{l}\text { Sri Lanka Bureau of } \\
\text { Foreign Employment } \\
\text { Ministry of Skills } \\
\text { Development and } \\
\text { Vocational Training }\end{array}$ \\
\hline
\end{tabular}




\begin{tabular}{l|c|c|c}
\hline Viet Nam & $\begin{array}{c}\text { Pre-departure trainings are provided } \\
\text { by recruitment agencies and include } \\
\text { information on workers' rights and } \\
\text { responsibilities, culture of the CoD, } \\
\text { laws and policies, complaints } \\
\text { mechanisms, remittances as well as } \\
\text { return and reintegration. }\end{array}$ & $\begin{array}{c}\text { In 2018, a project was presented by } \\
\text { the Ministry of Labour to encourage } \\
\text { the emigration of skilled workers } \\
\text { with professional or technical skills, } \\
\text { such as construction workers and } \\
\text { engineers (Nguyen et al., 2019). }\end{array}$ & $\begin{array}{c}\text { Ministry of Labour, } \\
\text { Invalids and Social } \\
\text { Affairs - Department of } \\
\text { Overseas Labour } \\
\text { (DOLAB) }\end{array}$ \\
Duration: 74 hours (ILO, 2014b). & \begin{tabular}{c} 
(ID) \\
\hline
\end{tabular} & & \\
\hline
\end{tabular}




\section{References}

AlJazeera (21 November 2020), "Philippines ends overseas travel ban on healthcare workers", Al Jazeera Media Network, www.aljazeera.com/news/2020/11/21/philippines-ends-overseas-travel-ban-onhealthcare-workers.

Al Murshidi, G. H. (2019), "Stem Education in the United Arab Emirates: Challenges and Possibilities", International Journal of Learning, Teaching and Educational Research, Vol.18, pp. 316-332, 10.26803/ijiter.18.12.18.

Alsahi, H. (10 November 2020), "COVID-19 and the Intensification of the GCC Workforce Nationalization Policies", Arab Reform Initiative, www.arab-reform.net/publication/covid-19-and-the-intensification-of-thegcc-workforce-nationalization-policies/.

ADB (2021), "Reaping the benefits of industry through skills development in high growth industries in Southeast Asia: Insights from Cambodia, Indonesia, the Philippines, and Viet Nam", Asian Development Bank, www.adb.org/publications/benefits-industry-skills-development-southeast-asia.

ADB (2018), "Asian Development Outlook 2018: How technology affects jobs", Asian Development Bank, http://dx.doi.org/10.22617/FLS189310-3.

ADB (2015), "Innovative strategies in technical and vocational education and training for accelerated human resource development in South Asia - Sri Lanka", Asian Development Bank, www.adb.org/publications/innovative-strategies-tech-voc-education-training-human-resource-

development-south-asia.

Aus dem Moore, J. P., V. Chandran and J. Schubert (2018), "The Future of Jobs in the Middle East", World Government Summit and McKinsey\&Company, www.mckinsey.com/ /media/mckinsey/featured\%20insights/middle\%20east\%20and\%20africa/are\%20mi ddle\%20east\%20workers\%20ready\%20for\%20the\%20impact\%20of\%20automation/the-future-of-jobs-inthe-middle-east.ashx.

Bhaskar, T.L.S. (14 April 2017), "India introduces pre-departure orientation for migrant workers", World Bank Blogs, https://blogs.worldbank.org/peoplemove/india-introduces-pre-departure-orientation-migrantworkers.

Boudreau, J. (8 January 2020), "Are High-Skill Occupations "Safe" from Automation?", Visier, https://www.visier.com/clarity/are-high-skill-occupations-safe-from-automation/.

Boudreau, J. (21 July 2016), “Will Automation 'terminate' Occupations", Visier, https://www.visier.com/clarity/will-automation-terminate-occupations-deconstructing-work-reveals-theanswer/.

British Council (2018), "Future skills supporting the UAE's future workforce", British Council, www.britishcouncil.ae/sites/default/files/bc futureskills english 1 mar18 3.pdf.

Castro-Palaganas, E., et al. (2017), "An examination of the causes, consequences, and policy responses to the migration of highly trained health personnel from the Philippines: the high cost of living/leaving-a mixed method study", Human Resources for Health, Vol.15/25, DOI: 10.1186/s12960-017-0198-z 
Cisco and Oxford Economics (2018), "Technology and the future of ASEAN jobs: The impact of Al on workers in ASEAN's six largest economies", Cisco, https://www.cisco.com/c/dam/global/en sg/assets/csr/pdf/technology-and-the-future-of-asean-jobs.pdf.

Colombo Process (2021), "Members", Columbo Process, www.colomboprocess.org/about-the-colomboprocess/members - sri-lanka|ChildVerticalTab 11 (accessed 10 February 2021).

De San José, C.A. (13 December 2019), "Future of Work: 20 Ways Work Will Change in 2020", Al/Work, https://allwork.space/2019/12/future-of-work-20-ways-work-will-change-in-2020/.

El-Saharty S., et al. (2020), "Fostering Human Capital in the Gulf Cooperation Council Countries", World Bank Group, https://openknowledge.worldbank.org/handle/10986/33946.

Enabel (1 March 2019), "PALIM - European Pilot Project Linking Moroccan ICT Development and Labour Shortages in Flander", Enabel - Belgium development agency, www.enabel.be/content/palim-europeanpilot-project-linking-moroccan-ict-development-and-labour-shortages-flanders.

Ernst \& Young (2015), "How will the GCC close the skills gap?", EYGM Limited, https://pdf4pro.com/cdn/how-will-the-gcc-close-the-skills-gap-ey-2bbd9d.pdf.

Ernst \& Young India (2019), "Developing skills in youth to succeed in the evolving South Asian economy", Background paper South Asia Youth Skills and Solutions Forum, UNICEF and EY India, https://www.unicef.org/rosa/media/4441/file/Developing skills in youth background.pdf.

Fattouh, B. and A. Sen (2021), "Economic Diversification in Arab Oil-Exporting Countries in the Context of Peak Oil and the Energy Transition", in Luciani G. and T. Moerenhout (2021), When Can Oil Economies Be Deemed Sustainable?, Palgrave Macmillan, Paris and New York.

Frey, C.B. and M.A. Osborne (2017), "The future of employment: How susceptible are jobs to computerisation?", Technological Forecasting and Social Change, Vol. 114, pp.254-280, https://doi.org/10.1016/j.techfore.2016.08.019.

GCC STAT (2019), "Data portal platform", GCC Statistical Center, https://dp.gccstat.org/en/DataAnalysis?yubK0edD5kWITTzkG03gw (accessed 29 January 2021).

GIZ and ILO (2016), "From Pakistan to the Gulf region: An analysis of links between labour markets, skills and the migration cycle", Deutsche Gesellschaft für Internationale Zusammenarbeit (GIZ) GmbH and International Labour Organization, www.ilo.org/islamabad/whatwedo/publications/WCMS 532696/lang-en/index.htm.

Government of India (2016), "Ministry of Skill Development \& Entrepreneurship joins hands with Ministry of External Affairs for implementation of the Pravasi Kaushal Vikas Yojana (PKVY)", Ministry of Skill Development \& Entrepreneurship, Press release.

Government of Kuwait (2017), "New Kuwait: Kuwait Vision 2035", New Kuwait, www.newkuwait.gov.kw/home.aspx.

Government of Nepal (2020), “Nepal Labour Migration Report 2020”, Ministry of Labour, Employment and Social Security, https://moless.gov.np/wp-content/uploads/2020/03/Migration-Report-2020-English.pdf.

Government of Nepal (2012), "Foreign Employment Policy 2068", Ministry of Labour, Employment and Social Security, www.skills.gov.np/uploads/newsFiles/4594 eccf972dfee35fdc1e7ae3c2334751fb 1478599773 2.pdf.

Government of Oman (2018), "Moving forward with confidence: Oman vision document", Government of Oman, www.2040.om/Oman2040-En.pdf. 
Government of Pakistan (2018), "National 'Skills for All' Strategy: A Roadmap for Skill Development in Pakistan", Ministry of Federal Education \& Professional Training Taskforce on Education, www.giz.de/de/downloads/giz2019-en-tvet-national-skills.pdf.

Government of Saudi Arabia (2016), "Vison 2030 Kingdom of Saudi Arabia", Government of Saudi Arabia, www.vision2030.gov.sa/en.

Government of Sri Lanka (2021), "Pre-departure", Sri Lanka Bureau of Foreign Employment, www.slbfe.lk/page.php?LID=1\&MID=52.

Government of Sri Lanka (2010), "National Strategy on Tertiary, Vocational Education, and Training Provision for Vulnerable People in Sri Lanka", Ministry of Youth Affairs and Skills Development supported by International Labour Organization, http://planipolis.iiep.unesco.org/sites/planipolis/files/ressources/sri lanka policy tvet vulnerable.pdf.

Government of the Philippines (2021), "Education \& Training", Department of labor and employment Overseas workers welfare administration, https://owwa.gov.ph/index.php/programs-services/educationtraining.

Gupta, Z. S. (15 February 2021), "Expat Exodus Adds To Gulf Region's Economic Diversification Challenges”, S\&P Global Ratings, www.spglobal.com/ratings/en/research/articles/210215-expat-exodus-adds-to-gulf-regions-economic-diversification-challenges-11800970.

Hilal, N. (2020), "Tourism in the Gulf Cooperation Council Countries as a Priority for Economic Prospects and Diversification", Journal of Tourism \& Hospitality, Vol.9/451.

Holzmann, R. (2018), "Managed Labor Migration in Afghanistan: Exploring Employment and Growth Opportunities for Afghanistan", World Bank Group, https://openknowledge.worldbank.org/handle/10986/29275.

ILO (2021), "Labour Migration in the Arab States", International Labour Organization, www.ilo.org/beirut/areasofwork/labour-migration/WCMS 514910/lang--en/index.htm $\quad$ (accessed 30 January 2021).

ILO (2020), "Skills shortages and labour migration in the field of information and communication technology in Canada, China, Germany, India, Indonesia, Singapore and Thailand", International Labour Organization, www.ilo.org/global/docs/WCMS 755663/lang--en/index.htm.

ILO (2019), "Skills shortages and labour migration in the field of information and communication technology in India, Indonesia and Thailand", International Labour Organization, www.ilo.org/sector/Resources/publications/WCMS 710031/lang--en/index.htm.

ILO (2018), "Skills and the Future of Work: Strategies for inclusive growth in Asia and the Pacific", International Labour Organization, www.ilo.org/asia/publications/skills-fow/lang--en/index.htm.

ILO (2014a), "Recognition of Prior Learning: Background and Proposal for a Pilot in India", International Labour Organization Country Office for India, https://www.ilo.org/wcmsp5/groups/public/---asia/---robangkok/---sro-new delhi/documents/publication/wcms 332261.pdf.

ILO (2014b), "Pre-departure training curriculum: Viet Nam to Malaysia - Facilitator's manual", International Labour Organization Regional Office for Asia and the Pacific, www.ilo.org/wcmsp5/groups/public/---asia/---ro-bangkok/---sro-bangkok/documents/publication/wcms 314221.pdf.

ILO STAT (2020a), "Employment distribution by economic activity", ILO modelled estimates, www.ilo.org/shinyapps/bulkexplorer16/?lang=en\&segment=indicator\&id=EMP 2EMP SEX ECO DT A.

ILO STAT (2020b), "Employment distribution by occupation (by sex and place of birth) (\%)", ILO STAT explorer, 
www.ilo.org/shinyapps/bulkexplorer48/?lang=en\&segment=indicator\&id=MST TEMP SEX CBR OCU DT A.

ILO STAT (2019), "Labor force participation rate (by sex and age)", ILO modelled estimates, www.ilo.org/shinyapps/bulkexplorer37/?lang=en\&segment=indicator\&id=EAP 2WAP SEX AGE RT A.

ILO STAT (2017), "Labor force distribution by education (by sex and age)", ILO STAT explorer, www.ilo.org/shinyapps/bulkexplorer41/?lang=en\&segment=indicator\&id=EAP TEAP SEX AGE EDU D TA.

Islam, S. (2019), "Science, Technology, Engineering and Mathematics (STEM): Liberating Women in the Middle East", World Journal of Education, Vol.9/3, pp.94-104, https://doi.org/10.5430/wje.v9n3p94.

ITU (2017), "ICT Facts and Figures 2017", International Telecommunication Union, https://www.itu.int/en/ITU-D/Statistics/Documents/facts/ICTFactsFigures2017.pdf.

Khan, S.M. and S. Sharma (2021), "Upskilling For The Future", National Skills Development Corporation India, https://adduae2021.org/attachments/ADD\%20-\%20Research\%20Papers Theme\%201 v2.pdf.

Lavonen, J. (2020), "Curriculum and Teacher Education Reforms in Finland That Support the Development of Competences for the Twenty-First Century". in Reimers, F. (eds), Audacious Education Purposes, Springer, Cham, https://doi.org/10.1007/978-3-030-41882-3 3.

Linkedln (2019a), "Global Talent Trends 2019", Linkedln Talent Solutions, https://business.linkedin.com/content/dam/me/business/en-us/talent-solutions/resources/pdfs/globaltalent-trends-2019.pdf.

LinkedIn (2019b), "Future of skills 2019: Anticipating what's next for your business, an Asia-Pacific edition", Linkedln Talent Solutions, https://business.linkedin.com/content/dam/me/business/en-us/talentsolutions/cx/2019/PDF/linkedin-future-of-skills-2019-apac-web-updated.pdf.

Nagraj, A. (27 January 2021), "Oman to impose higher visa fees for employing foreign nationals", Gulf Business, https://gulfbusiness.com/oman-to-impose-higher-visa-fees-for-employing-foreign-nationals/.

Nguyen, N.A. et al. (2019), "Assessment of Labor Export Activities in Vietnam", Journal of Asian Review of Public Affairs and Policy, Vol. 4/1, pp. 70-87.

OECD (2021a), Economic Outlook for Southeast Asia, China and India: Reallocating Resources for Digitalisation, OECD Publishing, Paris, https://doi.org/10.1787/711629f8-en.

OECD (2021b), Towards a Skills Strategy for Southeast Asia: Skills for Post-COVID Recovery and Growth, OECD Skills Studies, OECD Publishing, Paris, https://doi.org/10.1787/6db0907f-en.

OECD (2020), Job Creation and Local Economic Development 2020: Rebuilding Better, OECD Publishing, Paris, https://doi.org/10.1787/b02b2f39-en.

OECD (2019a), Economic Outlook for Southeast Asia, China and India 2020: Rethinking Education for the Digital Era, OECD Publishing, Paris, https://doi.org/10.1787/1ba6cde0-en.

OECD (2019b), OECD skills outlook 2019: Thriving in a Digital World, OECD Publishing, Paris, https://doi.org/10.1787/df80bc12-en.

OECD (2018a),"Putting faces to the jobs at risk of automation", Policy brief, OECD, https://www.oecd.org/employment/Automation-policy-brief-2018.pdf.

OECD (2018b), Perspectives on Global Development 2019: Rethinking Development Strategies, OECD Publishing, Paris, https://doi.org/10.1787/persp glob dev-2019-en.

OECD (2016), Perspectives on Global Development 2017: International Migration in a Shifting World, OECD Publishing, Paris, http://dx.doi.org/10.1787/persp glob dev-2017-en. 
Patunru A. A. and R. Uddarojat (2015), "Reducing the Financial Burden of Indonesian Migrant Workers", CIPS Policy Recommendations No. 1, Center for Indonesian Policy Studies, https://repository.cipsindonesia.org/media/269-reducing-the-financial-burden-of-indones-bb2686ee.pdf.

Peck, J.R. (2017), "Can Hiring Quotas Work? The Effect of the Nitaqat Program on the Saudi Private Sector", American Economic Journal: Economic Policy, Vol.9/2, pp.316-347.

Portulans Institute (2020), "The Network Readiness Index 2020: Accelerating Digital Transformation in a post-COVID Global Economy", https://networkreadinessindex.org/wp-content/uploads/2020/11/NRI-2020V8 28-11-2020.pdf.

PwC (2017a), "20th CEO survey: 20 years inside the mind of the CEO... What's next?", PwC, https://www.pwc.com/gx/en/ceo-survey/2017/pwc-ceo-20th-survey-report-2017.pdf.

PwC (2017b), "Empowering the GCC digital workforce: Building adaptable skills in the digital era", PwC, www.strategyand.pwc.com/m1/en/reports/empowering-the-gcc-digital-workforce-full-report.pdf.

Reza et al. (2018), "Innovation \& Excellence: BMET in migration \& skills development", Government of the People's Republic of Bangladesh and Bureau of Manpower, Employment and Training (BMET), https://bmet.portal.gov.bd/sites/default/files/files/bmet.portal.gov.bd/publications/d34cb593 3487 4eb3 9 90f c7070b21d486/BMET Annual Report 2017 Final 03.06.18.pdf.

SaMI (2021), "Access to skills", Safer Migration Project, www.sami.org.np/access-to-skills, (accessed 10 February 2021).

Shayah, H. and Z. Sun (2019), "Employment in the Gulf Cooperation Council (GCC) Countries - Current Issues and Future Trends", Advances in Social Science, Education and Humanities Research, Vol. 196, pp. 412-415, https://dx.doi.org/10.2991/ssphe-18.2019.94.

Smith, R.L. (2017), "Institutional Requirements and Policy Processes for Establishing managed migration with and in Afghanistan", The World Bank, https://openknowledge.worldbank.org/handle/10986/30269.

Tan, S.H. and I. Seet (2020), "Infrastructure and Pedagogy Innovation-A Differentiating Factor in TVET", in B. Panth and R. Maclean (eds.), "Anticipating and Preparing for Emerging Skills and Jobs", Education in the Asia-Pacific Region: Issues, Concerns and Prospects, Vol. 55, pp. 109-115, https://doi.org/10.1007/978-981-15-7018-6 14.

TESDA (2018), "National Technical Education and Skills Development Plan (NTESDP) 2018-2022", Technical Education and Skills Development Authority, www.tesda.gov.ph/About/TESDA/47

UAE Ministry of Cabinet Affairs (2015), "UAE National Innovation Strategy", Prime Minister's Office, https://u.ae/en/about-the-uae/strategies-initiatives-and-awards/federal-governments-strategies-andplans.

UNDESA (2020), International Migrant Stock 2020, United Nations Department of Economic and Social Affairs, Population Division, New York.

UNDESA (2019), World Population Prospects 2019, Online Edition Rev.1, United Nations Department of Economic and Social Affairs, Population Division, New York.

WEF (2020), "The Future of Jobs Report 2020", World Economic Forum, www3.weforum.org/docs/WEF Future of Jobs 2020.pdf.

WEF (2016), "The Future of Jobs: Employment, Skills and Workforce Strategy for the Fourth Industrial Revolution", World Economic Forum, www3.weforum.org/docs/WEF Future of Jobs.pdf.

WHO (2016), "Global strategy on human resources for health: workforce 2030", World Health Organization, https://apps.who.int/iris/bitstream/handle/10665/250368/9789241511131-

eng.pdf;jsessionid=14B11ED8B28BB262050B0C4B8F10E369? sequence=1. 
World Bank (2021a), "Resilience COVID-19 Crisis Through a Migration Lens" [Migrant remittance inflows (share of GDP)], World Bank Group, https://www.knomad.org/publication/migration-and-developmentbrief-34.

World Bank (2021b), "Percentage of graduates from Science, Technology, Engineering and Mathematics programmes in tertiary education, both sexes (\%)", World Development Indicators, https://databank.worldbank.org/source/education-statistics-\%5e-all-indicators (accessed 22 February 2021).

World Bank (2021c), "School enrolment, tertiary (\% gross)", World Development Indicators, https://databank. worldbank.org/reports. aspx? source=2\&series=SE. TER.ENRR\&country=PHL,AFG,KHM, BGD,CHN,IND,IDN,PAK,LKA,THA,VNM,NPL (accessed 22 February 2021).

World Bank (2019), "Economic Diversification for a Sustainable and Resilient GCC", World Bank Group, Gulf Economic Update, http://documents1.worldbank.org/curated/en/886531574883246643/pdf/Economic-Diversification-for-a-

Sustainable-and-Resilient-GCC.pdf.

World Bank (2018a), "The Jobs Agenda for the Gulf Cooperation Council Countries", World Bank Group, https://openknowledge.worldbank.org/bitstream/handle/10986/29741/125505-WP-

PUBLIC.pdf? sequence $=1$ \&isAllowed $=y$.

World Bank (2018b), "Institutional Assessment of Migration Systems in Bangladesh: Initial findings meant to inform future areas for bank support on policy reforms/capacity building", World Bank Group, http://documents1.worldbank.org/curated/en/446181539106128109/pdf/Institutional-assessment-of-

Bangladesh-migration-system.pdf.

World Bank (2018c), "Individuals using the Internet (\% of population)", World Development Indicators, https://databank.worldbank.org/reports.aspx? source=2\&series=IT.NET.USER.ZS\&country=AFG,BGD,IN D,IDN,NPL,PAK,PHL,LKA,VNM (accessed 16 March 2021).

World Bank (2018d), “A Migrant's Journey for Better Opportunities: The Case of Pakistan”, World Bank Group, http://documents1.worldbank.org/curated/en/540841530861637430/pdf/Pakistan-InternationalMobility-Draft-06.pdf.

Yeates, N. and J. Pillinger (2018), "International healthcare worker migration in Asia Pacific: International policy responses", Asia Pacific Viewpoint, Vol. 59/1, pp. 92-106.

Yuniarto, P. R., (2019), "Migrant Workers Empowerment through Vocational Education and CommunityBased Learning: A Study Case of Indonesian in Taiwan", Journal of Indonesian Social Sciences and Humanities, Vol. 9/2, pp. 113-129. 